\title{
THE SHRINKING TAX PREFERENCE FOR PENSION SAVINGS: AN ANALYSIS OF INCOME TAX CHANGES, 1985-2007
}

Gary Burtless and Eric Toder

CRR WP 2010-3

Date Submitted: April 2010

Date Released: April 2010

Center for Retirement Research at Boston College

Hovey House

140 Commonwealth Avenue

Chestnut Hill, MA 02467

Tel: 617-552-1762 Fax: 617-552-0191

The research reported herein was pursuant to a grant from the U.S. Social Security Administration (SSA) funded as part of the Retirement Research Consortium (RRC). The findings and conclusions expressed are solely those of the authors and do not represent the views of SSA, any agency of the Federal Government, the RRC, the Brookings Institution, the Urban Institute, or Boston College.

(C) 2010, by Gary Burtless and Eric Toder. All rights reserved. Short sections of text, not to exceed two paragraphs, may be quoted without explicit permission provided that full credit, including (C) notice, is given to the source. 


\title{
About the Center for Retirement Research
}

The Center for Retirement Research at Boston College, part of a consortium that includes parallel centers at the University of Michigan and the National Bureau of Economic Research, was established in 1998 through a grant from the Social Security Administration. The Center's mission is to produce first-class research and forge a strong link between the academic community and decision makers in the public and private sectors around an issue of critical importance to the nation's future. To achieve this mission, the Center sponsors a wide variety of research projects, transmits new findings to a broad audience, trains new scholars, and broadens access to valuable data sources.

\author{
Center for Retirement Research at Boston College \\ Hovey House \\ 140 Commonwealth Avenue \\ Chestnut Hill, MA 02467 \\ phone: 617-552-1762 fax: 617-552-0191 \\ e-mail: crr@bc.edu \\ www.bc.edu/crr
}

Affiliated Institutions:

The Brookings Institution

Massachusetts Institute of Technology

Syracuse University

Urban Institute 


\begin{abstract}
The value of the tax preference for pensions depends on the marginal tax schedule and on the tax treatment of income from assets held outside a pension account. We examine the change over time in the value of pension investing, accounting for changes in the tax schedule and in the treatment of equity and bond income. We find that changes in U.S. tax law, especially the treatment of equity income, have led to sizeable changes in the value of the pension tax preference. On balance the value of the pension tax preference to worker-savers is modestly lower than it was in the mid-1980s and substantially lower than it was in the late 1980s.
\end{abstract}




\section{The Shrinking Tax Preference for Pension Savings: An Analysis of Income Tax Changes, 1985-2007}

\section{Introduction}

THE FEDERAL INCOME TAX encourages saving in qualified retirement saving accounts by exempting from current tax the income accrued within these accounts. In addition, for most qualified retirement plans taxation of labor earnings contributed to the plan is deferred until the benefits are paid out in retirement. Workers who expect to be in a lower tax bracket when retired than when employed thus derive a second important advantage from saving in a qualified plan. For the less-common Roth or prepaid retirement plans, workers deposit after-tax instead of pretax dollars in accounts, but pay no additional tax upon withdrawal. The tax law provides a wide variety of qualified retirement saving plans for individual workers, for the self-employed, and for employees in firms that provide retirement plans to their workers.

The value of the tax preference for qualified plans compared with other investments depends on the marginal income tax rate a worker owes on ordinary income at various stages of the life cycle and the rules for taxing capital income received outside a qualified account. Because marginal income tax rates and the tax treatment of different forms of capital income have varied over time, the value of the tax preference for qualified retirement plans has varied as well. For example, tax law changes enacted in 2001 and 2003 increased the tax preference for long-term capital gains, provided a new tax preference for qualified dividends, and lowered marginal tax rates on ordinary income. Each of these changes reduced the benefit from saving in qualified retirement plans by increasing the relative after-tax return on savings accumulated outside of qualified plans.

This paper examines the change in the value of pension tax incentives per dollar of investment for representative workers. The calculations are performed from the perspective of workers who contemplate making new contributions into qualified plans. The study estimates the income tax liabilities of workers depending on whether their retirement savings are held inside or outside of qualified plans. We simulate the effects of the changes in the tax code that have occurred in recent years, emphasizing the effects of tax rate changes and shifts in the tax preference available to capital income earned outside of pension accounts. Because the tax benefit for contributing to pensions extends over a number of years, the net tax benefit is discounted and is measured as a percentage of the initial investment. 
Burman et al. (2004) and Toder, Harris and Lim (2009) have estimated the present value of the tax preference and its distribution across income groups. These estimates and those of the government assume that asset holdings in qualified plans would otherwise be invested in bonds that are taxed as ordinary income. More than half of all pension assets are invested in U.S. and foreign equities, however. Equities generate income flows that currently receive three kinds of tax preferences - deferral of tax on capital gains until realization, concessionary rates on realized long-term capital gains, and, since 2003 concessionary rates on qualified dividends. However, equities also generate higher average pretax returns than bonds. The tax saving per dollar invested in a qualified retirement plan rises with the pretax return on asset, but falls as the share of asset return included in taxable income falls. Assuming a constant equity premium over time, the relative tax saving from investing within a qualified plan has varied over time with changes in the effective tax rates (determined by both the statutory marginal rate and preferences) on investing outside a qualified plan. In this paper, we estimate representative workers' tax incentives for investing inside a qualified retirement plan, given the composition of representative investment portfolios and the change in tax concessions available to capital income outside retirement accounts.

The findings of the study can be summarized briefly. First, the value of investing inside a qualified plan depends crucially on the particular asset that workers intend to hold in their retirement savings accounts. Some or all of the capital income flows of certain kinds of assets, such as stocks, receive favorable tax treatment if the assets are held in an ordinary investment account. Within a qualified plan, however, all capital income accrues tax free. As a result of the changing tax treatment outside a qualified plan over time, especially for equity income, the net value of investing in a qualified plan has also varied considerably. The value of qualified plan treatment also depends on the nature of the alternative savings account in which workers accumulate retirement savings if they do not save inside a qualified plan. Savings accumulated inside a deferred annuity insurance contract obtains part of the favorable tax treatment provided to pension savings. Although workers must contribute to deferred annuity contracts with aftertax dollars and ultimately must pay tax on the investment income when payouts are distributed, taxation of income accrued within the account is deferred until the money is withdrawn, in contrast to ordinary savings vehicles in which accrued income is taxed annually. 
The tax preference or penalty on different forms of saving can be represented in different ways. For some economists, the correct norm for taxing saving is a consumption tax, which is neutral between present and future consumption. Under a consumption tax, there is effectively no tax on income from capital. Deposits in savings accounts are excluded from the tax base and tax is deferred until assets are withdrawn for consumption. Qualified retirement saving plans receive consumption tax treatment. Under this "consumption tax" norm, wage income is taxed at the statutory rate if the worker consumes all her income immediately, but is taxed at more than the statutory rate if saved for future consumption, to the extent there is a positive tax on investment income. The present value of all taxes associated with a single year's wages divided by the wage is by this standard viewed as the total tax rate on earnings. This total tax burden consists of the sum of the current tax on earnings, the present value of all taxes on future capital income from investing the proceeds of the year's earnings, and the present value of any tax paid when the accrued wealth from the year's earnings is withdrawn from an account for consumption. If the worker's marginal tax rate is the same when funds are withdrawn as when they are deposited, then present value of taxes on income saved is the same as the present value of taxes on income consumed immediately and the tax rate on wages is just equal to the statutory tax rate.

By this standard, our calculations show that the pension tax preference continues to be economically significant for U.S. workers, especially those with average and above-average lifetime earnings, those who are deciding where to locate their savings early in their careers, and those who expect to convert their retirement savings into an annuity. For a typical U.S. worker who wishes to invest in taxable bonds and expects to convert the bonds into an annuity at retirement, rules for qualified retirement plans reduce the tax rate on gross earnings by about 21 percentage points. Compared with accumulating bond investments inside an insurance contract, saving inside a pension account reduces the tax rate on gross earnings by about 13 percentage points. For typical workers who intend to invest in equities, the pension tax preference falls roughly in between these two figures. Finally, we find that changes in U.S. tax law, especially in the tax treatment of capital gains income and qualified stock dividends, have led to sizeable changes in the value of the pension tax preference. The value of the pension tax preference to worker-savers is lower under current law than it was in the mid-1980s and substantially lower than it was in the late 1980s. 
We also show changes over time in the pension tax liability under an income tax norm. By this income tax standard, all capital income would be taxable at the same rate as labor income. But there is no income tax on assets accrued within qualified plans. The effective rate of tax can be represented as the difference between the pretax return on assets with no tax and the after-tax return. If workers are in the same tax bracket when retired as when working, the effective tax rate on capital income within a retirement plan is zero, meaning that the pretax and after-tax returns from saving will be equal. But the effective tax rate can be negative or positive, depending on whether marginal tax rates at the time of withdrawal are lower or higher than marginal tax rates at the time funds are deposited.

The remainder of the paper is organized as follows. In the next section we describe the tax preference for pensions in detail, and we assess the definitions used by the federal government when it estimates tax expenditures on pensions. The following section describes our methods for estimating the pension tax preference under four recent tax laws. It is impossible to estimate reliably the value of the tax preference without knowing the current and future tax positions of a representative sample of workers. Our basic method is to use predicted lifetime earnings profiles for a small set of representative workers under stylized assumptions about workers' expectations of future tax laws. We assume that workers anticipate that both the current tax rate schedule and current rules about the taxation of capital income will remain unchanged over the remainder of their careers. Section 4 of the paper illustrates our simulation method with tabulations of the pension tax preference for a handful of workers under the 1985 law. Estimates of the change in value of the pension tax preference under successive laws are presented in Section 5. The paper ends with a brief summary.

\section{The Consumption Value of the Pension Tax Preference}

Many people save during their working careers in order to finance consumption after they retire. In the analysis below we evaluate alternative saving options in terms of their effects on workers’ capacity to pay for old-age consumption. ${ }^{1}$ We will distinguish among three basic

\footnotetext{
${ }^{1}$ We disregard the tax treatment of precautionary saving and saving for the purpose of leaving a bequest to heirs. Workers who accumulate savings for retirement should recognize that any funds left in their accounts at death will be passed on to heirs. If the tax treatment of bequests is an important consideration to them, the results of our analysis of retirement savings are incomplete. But few people will ever pay federal estate tax; data reported by the Tax Policy Center (2009) show that 99.8 percent of deaths trigger no estate tax under 2009 law. The worker saving for a bequest would also have to take into consideration the income tax treatment of assets held inside and outside of
} 
saving options offered under the federal tax code - saving in an ordinary investment account, saving inside a deferred annuity insurance policy, and saving in a tax-preferred pension account, such as an employer-provided pension plan or an individual retirement account (IRA). ${ }^{2}$ Later we consider investments in two basic asset classes, bonds and equity, since the tax treatment of these two assets, if held outside of a tax-preferred account, differs.

Ordinary labor and capital income is subject to income taxes in the year when it is received. Workers who save part of their current gross wage earnings, say, the sum $S$, in a standard investment account in year $a$ will be able to consume the following amount in a future year, $b$ :

(1) $C_{b}^{1}=S \cdot\left(1-\tau_{w a}\right) \prod_{i=a+1}^{b}\left[1+r\left(1-\tau_{k i}\right)\right]$;

where $\quad C_{b}^{1}=$ Consumption in year $b$ out of a standard investment account;

$S=$ Amount set aside from pre-tax earnings for savings;

$r=$ Gross annual rate of return on savings;

$\tau_{w i}=$ Marginal tax on ordinary income in year $i$;

$\tau_{k i}=$ Marginal tax on capital income in year $i$;

$a=$ Age at which contribution is made; and

$b=$ Age when savings are consumed.

The portion of gross earnings that is set aside in a standard investment account is taxed in the year when it is earned, say, at age $a$, leaving only $S \cdot\left(1-\tau_{w a}\right)$ for initial investment in the account. In years between the initial investment and the year when savings are consumed, say, at age $b$, the investment earnings in the account are subject to annual income taxes at rate $\tau_{k i}$, the income tax rate applied on capital income in year $i$. The annual after-tax return on investments held in the account is therefore $r \cdot\left(1-\tau_{k i}\right)$.

The U.S. income tax code has long provided partial relief from capital income taxation when investment returns are accrued inside a deferred annuity policy. Savings in a deferred annuity policy can increase without any current tax on investment income until the owner withdraws money from the policy. The purchase of the annuity contract is generally made out of

pension accounts and the tax situation of heirs when they receive bequests out of the two kinds of accounts. These considerations are beyond the scope of this study.

${ }^{2}$ Roth IRAs and Roth 401(k) plans offer tax preferences for retirement saving that operate differently from the tax preferences extended to standard pensions and IRAs. Currently, however, an overwhelming percentage of taxpreferred pension savings has been accumulated in standard pensions and IRAs, which we will focus on in this paper. 
a worker's after-tax income. If workers save part of their gross earnings in a deferred annuity plan, they will be able to consume the amount $C_{b}^{2}$ in a future year, where

(2) $C_{b}^{2}=S \cdot\left(1-\tau_{w a}\right) \cdot\left[\left(1-\tau_{w b}\right)(1+r)^{b-a}+\tau_{w b}\right]$.

As in a standard investment account, the gross wage amount set aside in the deferred annuity, $S$, is subject to taxation before the money can be placed in the account, so only $S \cdot\left(1-\tau_{w a}\right)$ is actually invested. When money is withdrawn from the account at age $b$, the total investment gain in the account, $S \cdot\left(1-\tau_{w a}\right) \cdot(1+r)^{b-a}-S \cdot\left(1-\tau_{w a}\right)$, is taxed at the rate $\tau_{w b}$.

The tax preference for pensions is usually more generous than the preference for savings held in a deferred annuity. The worker's labor earnings and investment income on savings held in a pension account are only subject to income tax when money is withdrawn from the account in retirement. Thus, consumption from savings set aside in the pension account, $C_{b}^{3}$, will be (3) $C_{b}^{3}=S \cdot\left(1-\tau_{w b}\right) \cdot(1+r)^{b-a}$.

In comparison with a deferred annuity, the tax preference for qualified pensions typically allows workers to enjoy higher consumption when money is withdrawn from the account. ${ }^{3}$ We can express the proportional gain in consumption as the ratio of consumption that can be financed from the pension account to the consumption that can be financed from the deferred annuity. This proportional gain is

(4) $\frac{C_{b}^{3}}{C_{b}^{2}}=\frac{\left(1-\tau_{w b}\right) \cdot(1+r)^{b-a}}{\left(1-\tau_{w a}\right) \cdot\left[\left(1-\tau_{w b}\right)(1+r)^{b-a}+\tau_{w b}\right]}$.

The gain depends on the worker's marginal tax rate on ordinary income when the wages are originally earned (at age $a$ ) and the tax rate when savings are withdrawn from the fund (at age $b$ ). If the tax rate is the same when contributions and withdrawals are made (that is, if $\left.\tau_{w a} \equiv \tau_{w b} \equiv \tau\right)$, then

$$
\frac{C_{b}^{3}}{C_{b}^{2}}=\frac{(1+r)^{b-a}}{\left[(1-\tau)(1+r)^{b-a}+\tau\right]}
$$

\footnotetext{
${ }^{3}$ An exception can occur if the worker faces a higher marginal tax rate when money is withdrawn from the account than when the contribution is made during the worker's active career. Even in this case the pension account can generate higher consumption if funds are held in the account long enough. See equation 4.
} 
The proportional advantage of saving in a pension account as opposed to a deferred annuity rises with increases in the effective marginal tax rate on capital income, the rate of return on savings, and the number of years in which saving is held in the investment account. The proportional advantage of saving in a pension account increases still further if $\tau_{w a}>\tau_{w b}$, that is, if the worker faces a higher marginal tax rate while working than when retired.

In comparison with accumulating savings in an ordinary investment account, the proportional consumption gain from saving in a qualified pension plan is

(5) $\frac{C_{b}^{3}}{C_{b}^{1}}=\frac{\left(1-\tau_{w b}\right) \prod_{i=a+1}^{b}(1+r)}{\left(1-\tau_{w a}\right) \prod_{i=a+1}^{b}\left[1+r\left(1-\tau_{k i}\right)\right]}$.

When $\tau_{w a} \equiv \tau_{w b} \equiv \tau_{k i} \equiv \tau$ for all $i$, then

(5a) $\frac{C_{b}^{3}}{C_{b}^{1}}=\left[\frac{1+r}{1+r(1-\tau)}\right]^{b-a}$.

The proportional advantage of saving in a pension account as opposed to a standard (not-taxpreferred) savings account rises with increases in the marginal tax rate, the rate of return on savings, and the number of years during which money is held in the savings account. If $\tau_{w a} \equiv \tau_{k i} \equiv \tau$, but $\tau_{w a} \neq \tau_{w b}$, then

(5b) $\frac{C_{b}^{3}}{C_{b}^{1}}=\left(\frac{1-\tau_{w b}}{1-\tau_{w a}}\right)\left[\frac{1+r}{1+r\left(1-\tau_{w a}\right)}\right]^{b-a}$.

Normally we expect the tax rate while working to exceed the rate after retirement, $\tau_{w a}>\tau_{w b}$. This increases the consumption gain from accumulating savings in a pension account rather than a standard savings account. If instead workers expect to face a higher tax rate in retirement than when they are employed, it may be advantageous to accumulate savings outside of a pension plan, that is, to pay taxes on labor income before it is deposited in a savings account rather than when it is withdrawn in retirement.

Calculating the value of the pension tax preference. Every year the Office of Management and Budget (OMB) and Congressional Joint Committee on Taxation (JCT) offer estimates of the aggregate value of the federal tax preference for pensions (see Figure 1). In 
recent years the OMB estimates have covered the tax expenditures on employer defined-benefit and defined-contribution pension plans (including 401(k) and 403(b) plans), IRAs, and Keogh plans for the self-employed. The estimates account for two components of the total tax expenditure on this preference: the failure of the government to collect income taxes on current labor compensation placed in worker pension accounts and the failure to collect taxes on the investment income earned inside of pension accounts. After estimating these two items, budget analysts subtract income taxes collected on money that is withdrawn from tax-preferred pension accounts. The taxes collected on pension withdrawals represent tax payments that were deferred in previous years because of the tax preference.

Measured in this way total tax expenditures for the exclusion of pension contributions and pension investment income represent one of the most expensive tax preferences in the income tax code. According to a Congressional Research Service analysis of JCT estimates, the tax preference for pensions was the largest single tax preference in 2006 (Hungerford 2006). ${ }^{4}$ Recent OMB estimates suggest the pension tax preference is currently the second most costly tax preference. Total tax expenditures on pension tax concessions amounted to \$117 billion in FY 2008, while tax expenditures for the exclusion of employer contributions to employee health plans were estimated to be $\$ 131$ billion (U.S. Office of Management and Budget 2009, Table 19.1). For purposes of comparison, direct federal outlays on Social Security Old-Age and Survivors benefits amounted to \$504 billion in FY 2008.

The annual cash-flow estimate of revenue loss from the pension tax preference does not provide a meaningful estimate of either the cost to the government or the value to savers of the amount they are allowed to deposit in qualified plans in any year. Instead, it shows the difference in revenue between what is raised this year under the current law and what would have been raised if the preference had never been enacted but pension contributions, account balances, and withdrawals were the same. If the pension tax preference were eliminated, the future present value of the revenue loss could be either larger or smaller than projected by either the OMB or JCT, depending on how quickly deposits in retirement accounts are growing over time. For example, Toder, Harris, and Lim (2009) estimate that the tax expenditure for saving in

\footnotetext{
4 The CRS analysis shows \$125 billion in FY 2006 tax expenditures for the net exclusion of pension contributions and investment earnings. The next most costly tax preferences were for reduced tax rates on stock dividends and long-term capital gains (\$92 billion), the exclusion of employer contributions for health care (\$91 billion), and the deduction for mortgage interest payments (\$69 billion). See Hungerford (2006), p. 4.
} 
all qualified accounts is about \$199 billion in 2012 using the OMB/JCT method, but that the present value of tax savings from new deposits in qualified accounts in 2010 is $\$ 230$ billion. $^{5}$ All of these estimates assume no change in economic behavior; that is, they assume that total saving in the economy is unchanged and that qualified accounts merely cause a shift in savings from one savings instrument to another one. ${ }^{6}$

The OMB, but not JCT, has also published estimates of the present discounted value of the tax concession provided to new pension contributions in a given year. According to OMB's description of its estimates for 2008,

The present-value estimates represent the revenue effects, net of future tax payments that follow from activities undertaken during calendar year 2008 which cause the deferrals or other longterm revenue effects. For instance, a pension contribution in 2008 would cause a deferral of tax payments on wages in 2008 and on pension fund earnings on this contribution (e.g., interest) in later years. In some future year, however, the 2008 pension contribution and accrued earnings will be paid out and taxes will be due; these receipts are included in the present-value estimate. (U.S. Office of Management and Budget 2009, p. 298)

The present-value estimates of the cost of the pension tax preference show a much larger tax loss from the preference than the cash-flow estimates described above. The present-value estimate of the tax loss suggests that new pension contributions in calendar year 2008 entail a long-run revenue loss of $\$ 226$ billion, nearly twice the estimated cash-flow revenue loss for fiscal year 2008.

The large OMB estimates of tax expenditures on pensions are often cited in critiques of the U.S. employer-based pension system (Munnell 1992; Ghilarducci 2008 and 2009). There is little doubt that the tax expenditures are heavily skewed toward high-income taxpayers, who have an above-average probability of participating in pension plans and would face aboveaverage marginal tax rates if pension contributions and investment earnings were included in current taxable income (Burman et al. 2004; Toder, Harris and Lim, 2009). In view of this fact, critics of the current employer-based pension system argue that the large tax expenditures for

\footnotetext{
${ }^{5}$ The baseline for these estimates is the Tax Policy Center's "current policy baseline” which assumes that the Bush tax cuts are extended and the temporarily higher 2009 AMT exemption amounts are extended and indexed to changes in the consumer price index.

${ }^{6}$ The cash-flow estimate of revenue loss is sensitive to the growth in contributions over time. If, for example, contributions decline relative to withdrawals (perhaps because of an aging population) the revenue pickup from deferred taxes collected on withdrawals could exceed the government's tax loss from the exclusion of new pension contributions, making the preference appear less costly than it is. The largest component of the revenue loss, however, is the loss from exemption of annual capital income taxes on income accrued within qualified plans. (Toder, Harris, and Lim, 2009)
} 
pension saving should be redirected toward lower income wage earners or reoriented to encourage much broader participation in employer-based retirement plans. About half of private-sector workers in the United States hold jobs that are not covered by an employer retirement plan (Burtless 2009). Part of the tax expenditure currently devoted to subsidizing participation in pension plans could be reallocated to public programs that encourage greater participation in workplace savings plans or to tax incentives that provide a more generous saving subsidy to workers with average and below-average incomes.

This study estimates how the economic value to workers of the retirement saving incentives has varied over time with changes in tax laws and also how it varies depending on the type of asset held in qualified accounts. OMB and JCT analysts assume that, in the absence of the pension tax preference, retirement savers would hold fully taxable assets. In fact, however, many retirement savers hold tax-preferred assets (equities) or hold debt or equity within insurance accounts that allow deferral, though not exemption, of taxes on investment income. Relaxing the assumption that pension assets would have otherwise been held in fully taxable accounts reduces the value of the tax preference and affects estimates of how it has changed over time.

For example, if the tax preference for saving inside insurance contracts is attractive for building up retirement savings, then the tax incentive for saving in a pension plan should be compared against that for saving in an insurance account rather than in an ordinary investment account. If people hold corporate equities inside accounts, then the estimate should account for the more favorable tax treatment of income earned on corporate stock compared with income earned on bonds or ordinary savings accounts. When a financial asset is held inside an ordinary investment account, capital gains earned when the asset is sold are customarily taxed at a rate below the marginal rate assessed on other household income. (Under current law, the asset must usually be held for a year if the capital gain is to qualify for the concessionary tax treatment.) Although the amount of the capital gains tax concession has varied over time, some concession has been provided in the U.S. tax code in nearly every year since 1921. In 2009, taxpayers who would otherwise face either a $10 \%$ or $15 \%$ tax on ordinary income were not taxed at all on their long-term capital gains from the sale of stock. Taxpayers who would otherwise face a marginal tax rate of $25 \%$ or more were required to pay a capital gains tax rate of just $15 \%$. Furthermore, since 2003 the income tax code has temporarily provided concessionary tax rates on "qualified" 
dividends paid by U.S. and many foreign corporations. In 2009 the concessionary tax rates were identical to those levied on long-term capital gains. The theory behind the reduced tax on qualified dividends is that the corporation has already paid a corporate income tax on its profits. When dividends are taxed at ordinary rates in the personal income tax, the profits earned by the corporation are doubly taxed. The tax concession for qualified dividends reduces the burden of double taxation.

Whatever the theory behind the special tax treatment of dividends and capital gains, there is no distinction within qualified accounts between holding bonds and stocks; both accrue income tax free. So the value of the pension tax concession per dollar of pretax income is much smaller if individuals are holding stocks than if they are holding bonds. If the concessionary tax rate on capital gains and dividends is low enough, there may be little benefit for workers to build up stock market wealth inside of pension funds instead of inside an ordinary investment account. $^{7}$ To see this, consider the ratio of retirement consumption out of a pension account and out of an ordinary investment account (equation 5). Assume the marginal tax on investment income is constant throughout the worker's career and is below the ordinary income tax rate, $\tau_{k i} \equiv \tau_{k}$ and $\tau_{k}<\tau_{w i}$ for all $i$. Then

(5c) $\frac{C_{b}^{3}}{C_{b}^{1}}=\left(\frac{1-\tau_{w b}}{1-\tau_{w a}}\right)\left[\frac{1+r}{1+r\left(1-\tau_{k}\right)}\right]^{b-a}$.

Whether it is advantageous to hold assets in a pension account clearly depends on the relationship among $\tau_{k}, \tau_{w a}$, and $\tau_{w b}$. As we have seen, for workers who face an ordinary marginal tax rate of $10 \%$ or $15 \%$, the 2009 tax on investment income from stocks paying qualified dividends was $0 \%$. When $\tau_{k}=0$, the choice of investing in a pension or ordinary investment account depends only on the worker's marginal tax rate when the wage is earned and when the money will be withdrawn from the account for consumption. If $\tau_{w b}<\tau_{w a}$, it is advantageous to hold stocks inside a pension account; if $\tau_{w b}>\tau_{w a}$, it is advantageous to hold stocks in an ordinary investment account; and if $\tau_{w b}=\tau_{w a}$, the worker's retirement consumption

\footnotetext{
${ }^{7}$ It could be advantageous to hold stocks outside a retirement account under the unusual situation where the worker faces a much higher marginal tax rate in retirement than when working and saving. In that case, qualified accounts (other than Roth accounts) substantially raise the tax burden on wages by deferring the tax until the worker's income is higher and this higher tax rate on wages could outweigh the benefit of a lower tax rate on investment income if preferential treatment of income from stocks makes the value of exemption small enough.
} 
is identical regardless of whether the investment is held inside or outside a tax-preferred pension account. As changes in the tax code increase the preference for investment income from assets held outside of pension accounts they reduce the financial advantages of accumulating those assets inside pension accounts. In the remainder of the paper we estimate how the tax preference for pension savings has varied under tax laws in effect since 1985.

\section{The tax simulation}

To assess the value of the pension tax preference for a given worker, we assume the worker first chooses an asset class in which to invest and then determines the investment account alternative that offers the highest consumption payoff in retirement. The value of the tax preference can then be measured as the reduction in the lifetime present value of income taxes collected on the worker's contribution to the account compared with the taxes that would be collected if the investment occurred outside of a pension. Alternatively, the value of the tax preference can be measured as the increase in the real after-tax rate of return on the worker's investment if it is held in a pension account versus some other kind of investment account. We calculate the value of the tax preference using both these measures. Using either concept workers must make a forecast of the marginal tax they will face, both on ordinary income and on the investment income they would receive if assets were held outside of a pension account. This forecast must cover each year from the year when wage income is originally earned to the year when money in the account is withdrawn for consumption. Obviously, this kind of forecast requires a large amount of very uncertain information. The worker must know the future income tax schedule and future rules for taxing capital income. In addition, the worker must make a forecast of future taxable income. The worker's marginal tax rate in a particular future year will be determined by the tax schedule in that year and his or her taxable income in the year.

Tax laws. We have performed these calculations under four different tax laws, those in effect in 1985, 1988, 2000, and 2007. The differences among these four tax laws are interesting for a couple of reasons. First, the marginal tax rate schedule varied across the four years. Second, the tax treatment of equity income varied widely as a result of changes in the treatment of long-term capital gains and dividends. The 1985 law was the last one in which the U.S. tax code contained a rising tax rate schedule with many marginal rates. In 1985 these ranged from $11 \%$ at the bottom up to $50 \%$ in the top tax bracket. In addition, the 1985 tax code contained a generous provision that sharply reduced the percentage of long-term capital gains included in 
taxable income. As a result, there was a large gap between the tax rate applied to ordinary income, interest, and dividends, on the one hand, and to capital gains, on the other. The tax law in effect in 1988 was the product of a major overhaul of the tax code enacted in 1986. That reform drastically reduced the number of tax brackets and cut the top marginal tax rate from 50\% to $28 \%$ (33\% for taxpayers subject to a phase-out of the benefits of exemptions and lower rates). Equally important, the 1986 tax reform eliminated the tax preference for long-term capital gains. All capital income, regardless of its form, was subject to the same marginal tax rate, and this rate was the same as that applied to taxpayers' wage income. Between 1988 and 2000 a variety of provisions in the tax code were changed, reversing some of the reforms enacted in 1986. By 2000 the number of tax brackets was increased modestly, and the top marginal tax rate had been raised from $33 \%$ to $39.6 \%$. Long-term capital gains were once again subject to a lower tax rate than the one that was imposed on ordinary income. The 2007 tax law offers an interesting comparison with the other three tax laws because it is the only one in which qualified dividends were subject to a special concessionary rate below the rate applied against ordinary income. In addition, the marginal tax rate schedule was lowered in comparison to the tax schedule in 2000, and the tax concession for long-term capital gains was modestly increased.

These variations in the tax code can obviously affect the value of the pension tax preference. The form of the pension tax preference remained essentially unchanged over the entire period. When a worker or employer makes a contribution to a qualified pension account or IRA out of current labor income the contribution is excluded from the worker's taxable income. Investment earnings inside the pension account are also excluded. Withdrawals from the account are taxed as ordinary income when they are withdrawn, and they may be subject to an additional penalty tax if they are withdrawn before the worker attains age 591/2. (In all the calculations below we assume workers delay withdrawals until the penalty tax no longer applies.) There are limits on total annual contributions to most types of pension accounts, such as IRAs and 401(k) plans, and these have varied over the period we analyze. However, in the analysis below we only consider the decision of workers to contribute a modest sum, say, $\$ 100$, to a pension account. Changes in the limits on how much workers can contribute to a pension have no effect on the tax preference available on the worker's initial investment. Nearly all U.S. workers with positive labor income have the right to make tax-preferred pension contributions or to have them made in their behalf by an employer. If they do not work for an employer offering 
a retirement plan, an overwhelming majority of workers can make tax-preferred contributions to a regular IRA. In the calculations below we estimate the financial advantage of investing in a tax-preferred pension plan under the assumption that the worker is eligible to do so.

Representative workers. Our analysis focuses on the tax preference available to a handful of representative workers. To make forecasts of workers' current and future labor income we use selected lifetime earnings profiles estimated by the Office of the Chief Actuary of the Social Security Administration. The actuary's office publishes estimates of representative lifetime earnings profiles based on tabulations of lifetime earnings in the Social Security Administration's Continuous Work History Sample, a file containing information on lifetime annual earnings for a representative sample of workers who have made payroll tax contributions to the Social Security system. The Chief Actuary publishes earnings estimates, by year of age from 21 through 64, for four representative workers (Clingman and Nichols 2007). The workers are classified as workers with "very low," “low," “medium,” and "high” lifetime earnings. Their earnings profiles are displayed in Figure 2, which shows each worker's annual earnings at a given age measured as a fraction of the U.S. economy-wide average wage in the year that the worker attains that age. All of the lifetime earnings profiles show the hump-back pattern of rising and then falling relative wages that characterizes the typical age-earnings profile. ${ }^{8}$

Each worker in our simulation is assigned one of the four lifetime earnings profiles displayed in Figure 2. In order to calculate the worker's exact earnings at a given age, we multiply the earnings ratio shown in the chart for that age by the estimated economy-wide average wage when the worker attains that age. The economy-wide average wage is in turn determined by the Social Security Administration's estimate of the "average annual wage” in the tax years we examine (1985, 1988, 2000, and 2007). In calendar years after the indicated tax year, the economy-wide average wage is assumed to rise $3.9 \%$ a year, the intermediate forecast of long-term wage growth assumed by the Social Security Trustees in their 2009 annual report (Board of Trustees OASDI 2009, p. 97). We also use the Trustees’ forecast of the long-term rise in the consumer price index, which is $2.8 \%$ a year.

\footnotetext{
${ }^{8}$ Even though the hump-back pattern of lifetime earnings is typical it is by no means universal. Some workers enjoy rising relative earnings throughout their careers, others experience a decline in wages starting at an early age, and still others have an erratic pattern with one or more earnings interruptions during their careers. See Bosworth, Burtless, and Steuerle (2000).
} 
To calculate the expected tax schedule in years after a contribution is made, we assume that tax brackets are indexed to the rate of wage growth. Under current law tax brackets are indexed to changes in average consumer prices rather than wages, but Congress has lifted the bracket amounts from time to time, and in our simulation we assume it will do so in the future. If Congress raises tax brackets in line with the rate of overall wage advance, average and marginal income tax rates would remain approximately stable across the U.S. wage distribution. To calculate taxable income it is necessary to estimate other components of family income besides the worker's wages. For married workers the most important additional source of family income is usually the labor income of a spouse. For each of our four representative workers, we simulate four alternative tax situations for married workers. A married worker may have a spouse who is a non-earner, a spouse who earns one-half of the annual wage of the worker, a spouse who earns exactly the same annual wage, and a spouse who earns twice the annual wage of the worker we consider. In all we simulate the tax positions of earners with four career earnings patterns (very low, low, medium, and high) and in five possible family situations (single, married / zero-earnings spouse, married / spouse with one-half of own earnings, married / spouse with equal earnings, and married / spouse with twice own earnings).

Taxable income. Our assumptions regarding a worker's earnings and that of a spouse allow us to predict a family's earned income in a given year, but they do not tell us how much taxable income the family will have in that year. To predict taxable income we use information derived from the Tax Policy Center micro-simulation model, based on data from the Public Use File (PUF) of individual income tax returns produced by the Statistics of Income (SOI) division of the Internal Revenue Service. ${ }^{9}$ In particular, we ranked workers in the Tax Policy Center file by their earned incomes (wages plus net self-employment income) and then divided them into five equal-size groups. (For married workers we calculated the sum of spouses' earnings and then divided by two.) Earners were then divided into four age groups (under age 35, 35-44 years old, 45-54 years old, and 55-64 years old) and into married and single earners. This classification scheme yields $5 \times 4 \times 2=40$ groups of earners. Within each of these groups we calculated the ratio of average taxable income to labor earnings. Taxable income is usually lower than earned income as a result of exemptions and deductions from income. In the lowest

\footnotetext{
${ }^{9}$ For a description of the data file and Tax Policy Center micro-simulation model, see Rohaly, Carasso, and Saleem (2005).
} 
earnings class, taxable income is frequently higher than earned income, not only because earned income is very low but also because family income is likely to include other taxable income items besides earnings. To estimate an earner's or a family's taxable income, we multiply predicted annual earnings by the appropriate taxable income / earnings ratio just described. This procedure allows us to calculate the earner's or the family's marginal tax on gross earned income, interest, dividends, and long-term capital gains for each year in the earner's working career.

To forecast tax rates during retirement we developed a similar procedure, using Social Security pensions rather than annual earnings as a basis for predicting taxable income. First, we calculated each worker's and each spouse's Social Security benefits based on the Social Security benefit formula and the lifetime earnings record that was imputed to the worker and spouse. In performing this calculation we assumed that both spouses have the same birth year and retire from work on their $65^{\text {th }}$ birthdays. At age 65 they are assumed to claim a Social Security retirement or dependent spouse benefit. Social Security benefits are the most common source of income in old age, and for elderly Americans who have low or moderate incomes Social Security is by far the most important source of retirement income (Social Security Administration 2009). We then calculated workers' taxable incomes in retirement as a multiple of their Social Security benefits. The relevant multiples were obtained using estimates derived from the Urban Institute's DYNASIM model (Favreault and Smith, 2004). ${ }^{10}$ One problem with this procedure is that it sometimes predicts a level of taxable income after retirement that is higher than it is for the same representative worker in the years immediately before retirement. As a check on our calculations we also performed our simulation under the added constraint that taxable income in the first post-retirement year could be no higher than it was, on average, between ages 61 and 64 . In years after age 65 we assume that taxable income increases at the same rate as Social Security benefits. $^{11}$

${ }^{10}$ Aged families in the DYNASIM sample were divided into those with single and married family heads when they were in their late 60s. Single-head and married-couple families were then ranked from lowest to highest by their lifetime earnings. Married-couple families were ranked by their shared lifetime earnings (that is, their total lifetime earnings divided by two). After earners or married couples were ranked in this way, they were divided into five equal-size groups. This classification scheme produces $2 \times 5=10$ groups of retired workers and families. For each of these 10 groups we calculated the ratio of average taxable income to average Social Security benefits in the DYNASIM sample.

${ }^{11}$ Note, however, that we also assume that income tax brackets increase in line with increases in economywide average wages rather than consumer prices. Since average wages are assumed to rise $1.1 \%$ a year faster than 
The procedures just described allow us to predict earners' taxable incomes for every age of a working career (ages 21 through 64) and the first year of retirement (age 65). If we assume that all of the worker's retirement nest egg is consumed at age 65, it is then straightforward to calculate the relevant marginal tax rates that would apply to earned income, interest income, dividends, and long-term capital gains at successive ages up through 65. We also consider the taxes workers face if they choose an alternative retirement consumption stream. Workers can convert their retirement savings into a level annuity that begins at age 65 and continues until they die. Workers who accumulate savings outside of a pension or insurance policy will purchase their annuities with after-tax dollars, and so their annuity withdrawals will be subject to special tax rules. Workers who accumulate savings in a deferred annuity insurance policy purchase their annuities in part with after-tax and in part with pre-tax dollars. Again, special tax rules are applied to these annuity payments (U.S. IRS 2009). We assume that when single workers retire, they convert their accumulation into a nominal, single-life, level annuity. Married workers purchase joint survivor annuities. We assume the annuity makes level monthly payments until the longer lived spouse dies. The annuity seller bases its price on the expected mortality experience of American men and women born in 1950, using mortality projections of the Social Security Actuary (Bell and Miller 2005). We assume the insurance company charges a small load factor to cover its profit requirements and possible adverse selection among people who buy annuities. In determining the sales price of an annuity, the insurance company assumes it will be able to invest the worker's funds at the long-term government bond yield. In this paper we assume that yield is $4.5 \%$.

In all of our calculations we assume that both workers and their spouses survive to their $65^{\text {th }}$ birthdays. After that age, however, there is a rising probability that workers and their spouses will die in successive future years. We use the mortality estimates of the Social Security Actuary to calculate the probability of death at successive ages after 64 (Bell and Miller 2005). This permits us to calculate expected taxes on annuity payouts over the worker's retirement and that of his or her spouse. When the worker or spouse dies, the Social Security pension declines. The percentage decline in the Social Security payment depends on the relative lifetime earnings of each of the spouses. Under our assumptions, the taxable income of the remaining spouse will

prices, our assumption means that retirees' taxable incomes will gradually fall in relation to tax brackets, possibly leading to a drop in marginal tax rates as retirees reach advanced ages. 
decline when the Social Security payment shrinks, and this may change the marginal tax rate that is applied to annuity payouts.

Income flows from assets. An overwhelming share of U.S. pension savings is invested in equities, bonds and other interest-bearing assets, and insurance contracts (see Table 1). A small percentage of pension holdings is invested in real estate. In 2006 and 2007 about two-thirds of pension holdings consisted of equities, and slightly more than one-quarter was invested in bonds and other interest-bearing securities. The financial crisis in late 2008 produced a sharp drop in worldwide equity prices, leading to a sizeable decline in the proportion of pension holdings invested in stocks and a surge in the percentage invested in bonds. Nonetheless, equity holdings accounted for well over half of all pension assets at the end of 2008.

To compare the taxes that workers pay on a marginal contribution into either a taxpreferred pension account or an alternative investment account we need to define the investment flows that are produced by different assets. We simplify the analysis by assuming that both equities and bonds generate a steady rate of return over time. ${ }^{12}$ We assume that bonds generate an annual return of 5\% and stocks produce annual returns of $8 \%$. Given our assumption about price inflation, this is equivalent to assuming that real bond returns will average $2.2 \%$ and real stock returns will average 5.2\% over the worker's investment horizon. The stock return forecast is close to the geometric mean real return on large capitalization stocks between 1960 and 2009. The bond return is close to the average post-World-War-II real yield on a bond portfolio that is equally split between high-quality corporate bonds and U.S. Treasury securities of varying maturities. To simplify the analysis we assume that all returns on a bond portfolio are received as taxable interest payments; bond investors do not obtain any capital gains on their investments.

If equities are held inside a pension fund or an insurance contract, it does not matter how equity returns are split between dividends and equity price appreciation. However, when stocks are held in an ordinary investment account the split between dividend and capital gain returns can have an appreciable impact on after-tax returns. Long-term capital gains have historically been more lightly taxed than dividends. (Short-term capital gains are taxed as ordinary income, although the tax treatment of short term capital losses and ordinary income losses differ.) In addition, savers who own stocks in an ordinary investment account can choose when to realize

\footnotetext{
12 This assumption is obviously unrealistic. Returns on all assets except the safest ones vary over time and are unpredictable. We think our simplification is useful for this exercise because it helps make the analysis tractable. More important, it probably approximates the expectations of many ordinary investors.
} 
capital gains, delaying realizations when their marginal tax rate is high and realizing capital gains when their tax rate is low. To reflect the important difference between the two kinds of equity returns we estimate the tax preference for pensions when investments are made in three kinds of stock - those with high capital gains and no dividends, those with no capital gains and high dividends, and those which provide a 2.5\% annual dividend and generate enough capital gains to produce a total nominal annual return of $8.0 \%$. In each case the total annual return on stocks is $8.0 \%$.

Even if capital gains are heavily favored in the tax code, the tax law still provides an incentive for investors who hold stocks outside of a pension or deferred annuity account to defer their realization of capital gains as long as possible. Since many retirement savers hold stocks in mutual fund accounts, this may not be practical. The mutual fund manager may periodically realize some capital gain income in order to achieve the fund's investment objectives. In this case, the retirement saver who holds the mutual fund outside of a pension or insurance account must report the capital gain income on his income tax return and pay capital gain taxes. ${ }^{13}$ In addition, some investors outside of mutual funds will realize gains either to rebalance their portfolios or because their expectations of future appreciation of assets they hold differ from those of the market. In our simulation we assume that one-third of past unrealized capital gains are realized each year, and investors who hold assets in ordinary investment accounts pay the long-term capital gains tax on these realizations.

In sum, our simulation compares expected tax liabilities and after-tax investment returns for five kinds of assets: (1) bonds; (2) all-capital-gain stocks; (3) stocks that pay 2.5\% dividends and provide the remainder of return as capital gains; (4) all-dividend stocks; and (5) deferred annuity insurance contracts offering the same pretax yield as bonds. In the case of the first four assets we compare savings accumulation and potential retirement consumption when the investments are held inside a tax-deferred pension account as opposed to inside a standard, nottax-preferred investment account. In the case of the last-named asset we are essentially comparing the value of tax deferral on bonds available inside a pension account and inside a

\footnotetext{
${ }^{13}$ For informative analyses of mutual fund capital gains realizations and their implications for investors' decisions to hold equity mutual funds inside or outside of tax-preferred accounts, see Poterba, Shoven, and Sialm (2001), Bergstresser and Poterba (2002), and Dammon, Spatt, and Zhang (2004).
} 
deferred annuity insurance contract. The gross return on the underlying asset, bonds, is the same in the pension account and the insurance contract. ${ }^{14}$

\section{Pension tax preference under 1985 law}

We report two kinds of estimate of the value of the tax preference offered to investments held inside of pension accounts compared with investments accumulated outside of pension accounts. The first is the change in the present discounted value of the tax liability on the gross wage contribution that is invested in the account. This is equal to the sum of the initial tax on the wage, the present value of taxes on future investment income from any portion of the wage that is saved, and the present value of taxes on future withdrawals from accumulated assets.

In comparing lifetime taxes across different kinds of investment accounts, we assume that the saver has the option of directing $\$ 100$ of gross wage income into alternative investment accounts. If the contribution out of gross wages is invested in a standard investment account or in an insurance contract, the worker must pay the relevant marginal tax rate on the $\$ 100$ before it is invested in the selected asset. If instead the contribution is placed in a tax-preferred pension account, all of the $\$ 100$ is available for initial investment. Thereafter, the investment income is subject to the special tax rules pertaining to the particular asset and to the particular type of investment account selected (see equations $1-3$ above). ${ }^{15}$ We discount all lifetime tax payments to the age when the contribution out of wage income is made. Future tax payments are discounted using the long-term predicted return on the asset in which contributions are invested. This means that future taxes on a bond investment are discounted at 5\% per year, and future

\footnotetext{
${ }^{14}$ It is possible to hold equities as well as bonds inside of an insurance contract. However, we do not think the contrast between holding equities inside an insurance contract and a pension plan is particularly informative. In both cases, the favorable tax treatment of capital gains and dividend income is lost inside the tax-preferred account. It may be open to question whether investors obtain the same return on bond investments when the bonds are held inside of an insurance contract and a pension account. When Vanguard customers purchase a bond fund inside a tax-deferred insurance contract they pay $0.20 \%$ to $0.25 \%$ higher annual fees than when they purchase the same or a similar bond fund in an ordinary investment account or in a tax-preferred pension account. Customers of T. Rowe Price pay fees that are approximately $0.40 \%$ higher in an insurance account compared with a pension account. The higher charges are the result of the higher cost of administering an insurance account, but they also reflect the fact that the insurance contract may offer more favorable payouts to customers under certain circumstances (such as the customer's early death or a steep decline in the value of bonds held in the account).

15 The change in a worker's taxable income is assumed to be so small that it does not affect the marginal tax rate that will be applied to ordinary or capital income in any future year.
} 
taxes on an equity investment are discounted at $8 \%$ a year. ${ }^{16}$ Once savers convert their retirement nest egg into an annuity at age 65 the discount rate is reduced to reflect the lower expected rate of return on the assets that back the annuity. Since we assume insurance companies only hold the safest bonds, mostly Treasury securities, to back their annuities, the assumed discount rate after age 65 matches the lower interest rate on these very safe securities, or $4.5 \%$.

A second measure of the tax preference available for pensions is the difference in the real rate of return that workers obtain on their pension savings compared with savings held in an alternative kind of investment account. To calculate the real internal rate of return on the worker's investment we assume that workers invest $S \cdot\left(1-\tau_{w a}\right)$ at age $a$. They receive a stream of after-tax payments, measured in prices at age $a$, from their investment account. We measure these withdrawals from the investment account in the year or years when the savings are consumed by workers. If the real internal rate of return on an investment held in a pension account is greater than the internal rate of return on the same type of investment held in an alternative kind of investment account, the pension account is tax favored.

Tax savings with bond investments under the 1985 law: An example. The tax saving enjoyed by pension investors is illustrated in Figure 3. The top panel in the chart shows the cumulative effective tax rate on a worker's gross earnings depending on whether they are invested in an ordinary investment account, a tax-preferred insurance plan, or a tax-preferred pension account. In all cases the worker's savings are invested in bonds that yield a 5\% pre-tax return. To calculate the tax rate that applies to gross wages, we assume the worker earns the medium wage and is married to someone who earns twice the medium wage. ${ }^{17}$ We compute tax rates that worker faces under the tax law in effect in 1985, assuming the 1985 tax rules remained in effect throughout the worker's lifetime. The top panel in Figure 3 shows the cumulative effective tax on gross earnings placed in the investment account. This tax is shown for contributions at successive ages from 21 through 64, ages when the worker is assumed to earn taxable wages. We assume all the proceeds from the investment account, after taxes are paid on

${ }^{16}$ Bear in mind that the higher expected return on equities provides compensation to investors for the added risk they accept when investing in a riskier asset. To reflect this additional risk, the future returns must also be discounted at a higher rate.

${ }^{17}$ Recall that we are referring here to the medium wage profile as defined by the Social Security actuaries, not the median wage across all workers in the economy. 
withdrawals, are consumed immediately after the worker retires at age 65 . Note that the cumulative tax on the gross wage contribution is the same, regardless of the age of contribution, in the case of investments made into a pension account. The contribution is simply taxed at the marginal tax on ordinary income when the retired worker is 65 years old. When gross earnings are allocated to the other two kinds of account, gross earnings are also taxed in the year when they are earned. Note that this marginal tax rate rises with the worker's annual earnings. In the case of the insurance account, the investment income built up in the account is also taxed when it is withdrawn at age 65. When money is placed in an ordinary investment account, it is not taxed when it is withdrawn, but the investment income is subject to tax every year after the year of contribution. For a worker who contributes to an ordinary investment account at age 31, the cumulative tax on bond earnings under the 1985 law is almost 60\% versus a tax rate of just 25\% when savings is accumulated in a pension account.

The lower panel of Figure 3 shows the size of the tax preference for pension investments compared with bond investments in the other two kinds of account. For 31-year-old workers who are choosing where to place their retirement savings, the choice is straightforward. The cumulative tax rate will be 21 percentage points lower in the pension account compared with the insurance account and 35 percentage points lower in the pension account compared with the ordinary investment account. Younger workers obtain a less generous tax preference for pension savings because the tax on current labor income is lower when wages and taxable income are lower. For older workers who plan to set aside part of their wages for retirement savings the tax preference for accumulating savings in a pension account is also smaller. For contributions at age 64 the tax preference disappears. At older ages workers can take advantage of fewer years of tax-deferred investment earnings in the pension account (see equations 4 and 5).

When workers increase the span of retirement years over which they make withdrawals from their investment account, the tax advantage of saving in a pension account typically rises. Figure 4 shows the tax preference for accumulating savings in a pension account when workers convert their retirement nest egg into a joint survivor annuity at age 65. The other circumstances of the worker are identical to those facing the worker in Figure 3. The top panel shows the cumulative tax rate on the worker's gross wage contribution into the different kinds of account. The bottom panel shows the tax preference for saving in a pension account for successive ages of contribution into the account. The lower line in the bottom panel shows the tax preference for 
pension saving compared to saving in an ordinary investment account. At each age of contribution this tax preference is 8 to 11 percentage points greater when workers withdraw their funds in an annuity as opposed to at age $65 .{ }^{18}$ When the worker's savings are held in a pension account, the tax deferral on wage and investment income is extended for number of years, reducing the present discounted value of taxes paid. In addition, since the worker's marginal tax rate may decline over his or her retirement, tax payments are reduced still further. In the case of savings accumulated in an ordinary investment account, the conversion of savings into an annuity increases the worker's lifetime tax payments compared with the situation when all savings are withdrawn at age 65. Even though the withdrawals from an annuity purchased with after-tax dollars are more lightly taxed than withdrawals from an annuity purchased with beforetax dollars, all of the tax payments after age 65 represent an additional tax burden on an ordinary investment account above the burden the worker would bear if savings from the account were entirely consumed at age 65.

Figure 5 shows an alternative way of viewing the tax preference available to pension savers. The top panel in the chart shows the real after-tax internal rate of return on the worker's net investment, with a separate calculation of the return for each successive age between 21 and 64 when an investment might be made. In each case we consider the worker's "net investment” to be the after-tax investment he or she could make after paying taxes on gross wage income earned in the year of contribution. The circumstances of the worker are the same as those of the saver considered in Figure 4. The worker has a medium age-earnings profile and is married to a spouse who earns exactly twice the worker's wage each year. Regardless of the type of investment account the worker chooses, funds are invested in taxable bonds. When the worker reaches age 65, money in the account is converted into a level, joint survivor annuity. In viewing the results displayed in the top panel, bear in mind that the pre-tax real rate of return on bonds is assumed to be 2.2\%. The real after-tax rate of return falls short of this benchmark for investments held in ordinary investment accounts and deferred annuities. Even after workers pay taxes on the wages before investing in these kinds of accounts, returns are taxed again at least once before savings can be used for consumption. The shortfall is smaller in the case of

\footnotetext{
${ }^{18}$ This reflects the fact that with capital income taxable, the present value of taxes on this year's wage rises the longer consumption from the wage is deferred. Annuities raise the present value of taxes compared with lump sum distributions that are consumed because they extend the time period over which consumption is deferred and increase the present value of capital income associated with the initial wage.
} 
investments held inside a pension account, especially investments made early in a worker's career, because the tax on investment income is deferred until age 65 rather than paid each year of the worker's career. In the case of investments made in a pension account, the real rate of return on the worker's "net” contribution can exceed 2.2\%. The net contribution is calculated by subtracting the tax on wage income the worker would pay if the wages were used for current consumption. (This is in fact the tax that is paid before the worker can make a contribution into either an ordinary investment account or a deferred annuity product.) It is possible, of course, that this tax rate is higher than the one the worker will face after retirement. In that case, the after-tax return on the worker's "net” contribution will exceed the pre-tax return. In Figure 5 this is precisely the situation of the wage earner between ages 31 and 58, when the family's taxable income under the 1985 law pushed it into an income tax bracket where the tax rate exceeded the tax rate it would face after retirement.

The lower panel in Figure 5 shows the improvement in rate of return that the worker experiences at successive ages as a result of saving in a pension account rather than in the other two kinds of account. The difference in the rate of return is larger in the case of investment in an ordinary account compared with an insurance account, especially for wage contributions made early in a career. The clear message in Figures 3 to 5 is that middle- to high-income retirement savers in 1985 who wished to invest their savings in taxable bonds could expect to enjoy a sizeable improvement in retirement consumption if they accumulated their savings in a pension account rather than an ordinary investment account or a deferred annuity.

Tax savings with equity investments under the 1985 law. Equity investment offers savers an opportunity to obtain a tax preference, even if the investment occurs in a standard investment account. For most taxpayers in 1985 this tax preference was not as generous as the one provided to savers who invested in a pension account. Nonetheless, the net tax preference available in the pension account depended critically on the type of income generated by an equity investment. The pension tax preference was substantially smaller in the case of equity holdings that generated capital gain income rather than dividends. Figure 6 shows that the tax reduction workers obtain on their gross wage income depends on what type of equity they own and where they place their equity investment. The top panel shows the cumulative tax that savers pay on 
their gross wages for three kinds of investment. ${ }^{19}$ The flat line in the chart shows the tax paid on purchases of any kind of equity if it is held inside a pension account. The tax rate is identical to the one shown for pension account savings in Figure 4, where savings are invested in bonds rather than stocks. The two other lines in the top panel of Figure 6 refer to the cumulative tax paid on equities held in an ordinary investment account. The top line shows the tax rate on equities which pay $2.5 \%$ dividends and return the rest of their $8 \%$ annual returns as capital gain. We assume one-third of the cumulative long-term gains are realized by the investor in successive years. The middle line shows the tax when all of the equity income is returned to investors as capital gains. If the investor realized a smaller percentage of cumulative capital gains each year, the tax rate would be lower. It is obvious, however, that the pension tax preference for holding equities was smaller in the case of high-capital-gains stocks compared with dividend-paying stocks.

The lower panel in Figure 6 makes this point even more vividly. It shows the pension tax advantage at successive ages of contribution for three kinds of equity investments - those that yield all of their income through capital gains, those that yield part of their income through capital gains and part through dividends, and those that pay all their income to shareholders as dividends. In all three cases the gross income flow to shareholders is assumed to be $8 \%$ a year. Under the 1985 tax law the all-capital-gain stock enjoyed a sizeable tax preference if held outside of a pension fund. Compared with the tax collected on an all-dividend stock, the cumulative tax on an all-capital-gain stock investment is at least 30 percentage points lower for investments made before age 29; it is at least 20 percentage points lower for investments made before age 42. Even so, the worker whose tax position is displayed in the chart would have been better off locating his or her retirement savings inside a pension account, especially between ages 31 and 58 when the highest marginal tax rate on earnings applies. The calculations displayed in the chart indicate, however, that a sizeable fraction of the tax preference available through investing in a pension fund was also available to retirement savers who invested in high-capitalgain stocks but held them in an ordinary investment account.

19 The saver once again is assumed to earn the medium lifetime wage and to be married to a spouse who earns twice the medium wage. The tax is calculated under the 1985 tax law, which excluded $60 \%$ of realized capital gain income from taxation. The worker and spouse are assumed to convert their retirement savings into a level, joint survivor annuity at age 65 . 
The tax preference for high and low earners under the 1985 law. The results presented so far refer to a single type of earner, one who earns the medium lifetime wage and is married to a spouse who earns double that wage. The tax preference varies, of course, with the worker's wage and family circumstances. Figure 7 presents estimates of the tax preference for workers with different lifetime earnings profiles. Once again, the results are estimated using the tax rules and marginal tax rate schedule in effect in 1985. We show how much the cumulative tax on the worker's gross earnings would rise if the investments were held in an ordinary investment account rather than inside a tax-preferred pension account. The results in the top panel show the tax preference for pensions when the worker invests in taxable bonds; the results in the bottom panel show the tax preference when savings are invested in all-capital-gain stocks. We consider investments made at five ages (24, 29, 39, 49, and 59), and we estimate the tax preference for four earners (those with very low, low, medium, and high lifetime earnings). In every case the earner is assumed to have a spouse who earns the same wage.

The results in Figure 7 show as expected that the tax preference is typically larger for workers who earn higher wages and can anticipate facing higher marginal tax rates over their careers. The tax preference also tends to be larger for account contributions that occur earlier in the worker's career or that occur when the worker faces higher marginal tax rates on ordinary income. A notable finding in the chart is that the pension tax preference is considerably larger for bond investment than it is for investment in stocks that generate most of their income through capital gains (Poterba, Shoven, and Sialm 2001; Dammon, Spatt, and Zhang 2004). The gap is biggest for contributions made early in a worker's career, and is quite modest near the end of a career. The benefit of compounding interest at a higher after-tax rate of return is, not surprisingly, worth more if done over a longer time period. If the 1985 tax preference for pension savings were estimated under the assumption that the pension portfolio consists solely of bonds, the calculation would produce a substantial overstatement of the value of the tax preference.

\section{Pension tax preference under later laws}

The 1985 tax law provided a very generous tax preference to realized long-term capital gains, but it did not offer special tax preferences for other capital income derived from stocks or taxable bonds. The 1986 tax reform removed the special tax preference for long-term capital gains and at the same time reduced marginal tax rates on many wage earners, especially those in high marginal tax brackets. After 1990 tax preferences for equity income were restored and even 
expanded. The tax preference for long-term capital gains was re-introduced in 1990 and liberalized in 1997 and 2003. Starting in 2003 a tax preference was introduced for qualified dividend income. How did these changes affect the value of the pension tax preference?

Calculations for a representative wage earner. Table 2 shows our estimates of the net tax preference for pension savings compared with the tax that would be paid on the same kind of asset but held in a different kind of investment account. In all cases we calculate the increase in the tax rate on gross wage income that the worker would incur if he or she shifted the asset from a pension account into an ordinary investment account or an insurance plan. The top two sections of the table show the increased tax rate workers would face on bonds held in an ordinary account and in an insurance plan. The bottom three sections show the tax increase workers would face if three kinds of equity were located in a standard investment account as opposed to a pension. In all cases we assume the worker earns the medium lifetime wage and is married to a spouse who earns double that wage. The tax rate is calculated under the assumption that the net withdrawals from the investment, insurance, or pension account are consumed immediately after retirement at age 65. Calculations are performed at four ages (29, 39, 49, and 59) and under the tax rules and schedules in effect for four years (1985, 1988, 2000, and 2007).

For the tax situations presented in Table 2, changes in the tax code since 1985 have on balance reduced the tax preference available to pension savers. The most noticeable declines occurred in the case of dividend-paying equities. The decline is smaller in the case of equities where all of the saver's investment income is derived from long-term capital gains. The net tax preference for holding taxable bonds in a pension account also declined, but the decline was smaller if the worker's investment alternative was to locate his or her bond holdings in an insurance policy. The results in Table 2 also shed light on the effects of individual tax laws. For example, the pension tax preference for bond investment and investment in all-dividend equities fell between 1985 and 1988, primarily because of the reduction in marginal tax rates. In contrast, the tax preference for equities which yield large capital gains increased noticeably. Because these stocks lost an important tax preference if held in regular investment accounts as a result of the 1986 Tax Reform Act, the pension tax preference became more valuable. Changes in tax law after 1988 did not have an important effect on the value of pension tax preference for bond holdings, but they did substantially reduce the pension tax preference for equity holdings. 
Table 3 shows results for workers who convert their retirement savings into a level, joint survivor annuity after retirement. In all other respects the earnings, family circumstances, and tax positions of the taxpayers in Table 3 are the same as those shown in Table 2. As we have seen, workers who expect to consume their retirement savings over a lengthy retirement rather than early in their retirement derive bigger tax benefits from locating their retirement savings in a pension account. Thus, the values of the tax preferences displayed in Table 3 are larger than the comparable preferences shown in Table 2. However, the changes in the value of the pension tax preference between 1985 and 2007 are similar, though somewhat smaller, for workers in the same tax position who invest in the same assets. Both tables show that the tax preference for pension savings is economically significant for workers at every stage of their career and under all four of the tax laws considered here. For moderate- to high-income taxpayers it still pays to accumulate retirement savings in a tax-preferred pension account. The tax preference is, however, noticeably smaller than it was in the 1980s.

Calculations for a cross-section of workers. The estimates just described can be performed for workers with varying age-earnings profiles and in a variety of family situations. In the analysis that follows we present tabulations for a cross section of workers at four earnings levels, "very low”, “low”, "medium”, and "high” (see Figure 2). Figures 8 and 9 show the increase in the tax rate on gross wages that workers with each earnings profile would incur if they shift the indicated asset from a pension account into an ordinary investment account or into an insurance plan. Figure 8 displays the expected tax increase if bond investments are shifted from a pension account into an ordinary investment account (top panel) or into an insurance contract (lower panel). The three panels in Figure 9 show the expected tax increases on three kinds of equity investment if they are shifted from a pension account into an ordinary investment account. Both charts show how the expected tax increase differs across lifetime earnings levels and under the four tax laws we consider in this paper.

In order to calculate the tax preference for a composite worker with "high" lifetime wages, we first need to estimate the relevant population weights of high-wage workers at different ages and in different family circumstances. To obtain these weights we performed tabulations of the public-use version of the Census Bureau's Current Population Survey (CPS) files for 2008. The files for February to April 2008 contain information on each worker's age, marital status, earnings in 2007, and spouse’s earnings, if any, in 2007. These data permit us to 
calculate the percentage of 2007 earners in population cells defined by broad earnings level, age, marital status, and ratio of spouse's earnings to own earnings. ${ }^{20}$ For workers with a combination of age and earnings level placing them in the "high" lifetime wage group, it is then straightforward to calculate the percentage of high earners in different age, marital status, and spouse-earnings-ratio groups. With this information we can assign approximate weights to each tax situation covered by our analysis. Under the 1985 tax law, for example, earners with high lifetime earnings would on average face a $49 \%$ cumulative tax on their gross earned income if savings out of wages were invested in bonds and placed in an ordinary investment account. In contrast, they would face a cumulative tax rate of just $20 \%$ if the same bond investment were placed in a pension account. The tax-rate difference, 29 percentage points, represents the tax advantage for locating bond investments in a pension account rather than an ordinary investment account (see top panel in Figure 8). This 29 percentage point estimate reflects the weighted average of our estimates for high lifetime earners in all the tax situations covered by our analysis. ${ }^{21}$ Using the same set of weights to estimate the tax preference, we find that the pension preference for bond investment fell to 28 percentage points under the 1988 tax law, to 27 percentage points under the 2000 tax law, and to 24 percentage points under the 2007 tax law. At the other end of the earnings scale, the tax preference for pension saving increased sharply as a result of the 1986 Tax Reform Act and then fell modestly between 1988 and 2007. Workers with low and medium lifetime earnings saw only small changes in the pension tax preference when they invested in bonds. The same general patterns also apply when calculating the tax preference for holding bonds in a pension account as opposed to an insurance policy (see lower panel of Figure 8).

By far the largest portion of pension and IRA saving is invested in equities (Table 1). Figure 9 shows the trend in the tax preference for equities when they are held in a pension account versus an ordinary investment account. The top panel shows the weighted average tax

${ }^{20}$ We classified 21-64 year-olds with 2007 earnings in 7 broad annual earnings groups (\$1 to $\$ 9,999, \$ 10,000$ to $\$ 19,999$, etc.), 9 age groups (age 21-24, 25-29, 30-34, etc.), 2 marital status groups, and, for married earners, into 4 spouse-earnings groups depending on the ratio of a spouse's earnings to own earnings.

${ }^{21}$ The population weights used to obtain this estimate are based on the observed distribution of among all 2164 year-olds who had positive labor earnings in 2007. An alternative way to calculate the weights is to consider only the workers who say they are offered a pension at their place of employment. Older workers and workers earning higher wages tend to be offered workplace pensions more frequently than workers who are young and earn lower wages. However, when we use an alternative set of weights that reflects the population weights of workers who are offered workplace pensions, the basic pattern of results displayed in Figures 8 and 9 is not greatly affected. 
preference for equities that do not pay dividends, that is, for stocks that pay out all returns as capital gains. This type of equity investment received a generous tax preference if held outside of a pension account in 1985, so the net preference for holding it in a pension account was relatively modest. With the elimination of the capital gains tax preference in the 1986 Tax Reform Act, workers obtained a sharply higher tax preference when this kind of equity was held in a pension account rather than an ordinary investment account. The re-introduction of the tax preference for capital gains after 1990 and the liberalization of that tax preference after 2000 reduced the value of the pension tax preference for this kind of equity. By 2007 the pension tax preference was smaller for low, medium, and high wage earners than it had been in 1985. Only in the case of earners with very low lifetime wages was the pension tax preference greater than it had been in 1985.

This same general pattern is also apparent in the bottom two panels of Figure 9. These show the weighted average pension tax preference if some or all equity income is received by investors in the form of regular dividend payments. For low, medium, and high lifetime earners, the value of the tax preference falls between 1985 and 2007. The decline is particularly large between 2000 and 2007, reflecting the new tax preference extended to qualified stock dividends earned in an ordinary investment account. The falloff in the pension tax preference is biggest in the bottom panel of the chart, which shows the situations of workers who invest in high-dividend stocks. In contrast with the shrinking pension tax preference enjoyed by earners with higher lifetime incomes, those with very low lifetime wages obtained a bigger pension tax preference on equity investments in 2007 than they did in 1985. In 1985 these earners faced very low marginal tax rates throughout their careers and in retirement, so the value of the pension tax preference was quite modest. The preference became more valuable under later tax laws because workers with very low earnings were more likely to owe modest taxes on their marginal earnings and on a marginal increase in their retirement incomes.

The results in Figures 8 and 9 suggest that workers in all lifetime earnings groups obtained a significant net income gain from holding stocks and bonds in a pension account rather than an alternative kind of investment account. For workers with moderate and high incomes the tax advantage of pension saving declined over the analysis period but it did not disappear altogether. This finding is confirmed when we calculate the real rates of return that workers with high, medium, low, and very low lifetime earnings would have obtained on assets held inside and 
outside of a pension account under the four tax laws (see Appendix Table 1). The calculations show, not surprisingly, that the rate of return improvement from investing in a pension plan is considerably larger for workers with higher lifetime earnings. Consistent with the results shown in Figures 8 and 9, the analysis of rates of return shows that workers with very low lifetime earnings derived bigger gains from pension investment in 2007 than in 1985. In contrast, workers with low, middle, and high lifetime earnings on balance derived smaller benefits from pension investment under the 2007 law than under the 1985 law.

Pension tax preference for the workforce as a whole. The results in Figures 8 and 9 can be used to estimate the approximate tax preference obtained by 21-64 year-old workers if they hold particular assets in a pension account rather than in an alternative kind of investment account. The approximation weights the pension tax preference obtained by high, medium, low, and very low earners by the population proportions in each age group. In the 2008 CPS files we estimate that the proportions in the four earnings groups were $31 \%, 23 \%, 25 \%$, and $21 \%$, respectively. If we focus solely on the workers who are offered a workplace pension by their employers, the proportions are 49\%, 30\%, 13\%, and 7\%, respectively. The offer of a workplace pension is heavily tilted in favor of workers with high and medium earnings. Workers with low and especially with very low earnings are much less likely to work for an employer that offers either a traditional or a 401(k) pension plan. An overwhelming majority of uncovered workers is still entitled to receive the pension tax preference, but the preference would be obtained through an IRA rather than under an employer-provided plan.

Table 4 shows the workforce-average pension tax preference for bond and equity investments held in pension plans rather than an alternative kind of investment account. To calculate the results in the table we use population weights derived from all 21-64 year-old workers who had positive earnings in 2007. The table shows the weighted-average increase in taxes on gross earnings workers would experience if their investments were placed in an ordinary investment account or an insurance account rather than in a pension account. In the top panel of the table we show estimates of the pension tax preference when all savings in the accounts are consumed immediately after retirement at age 65. The lower panel shows tax-rate increases when savings accumulated in an account are converted to a level annuity starting at age 65. For reasons mentioned earlier, the pension tax preference is nearly always greater if workers convert their savings into an annuity rather than consume all of their savings immediately after 
retirement. (The benefits of pension investment measured as changes in the real rate of return are displayed in Appendix Table 2. The estimates in that table are based on the same sample weights used to derive estimates in Table 4.)

The results in Table 4 contain a number of lessons about the value of the pension tax preference. First, for workers who wish to invest in taxable bonds, accumulating savings inside a deferred annuity account provides slightly over sixty percent of the tax advantage provided by investing inside a pension account. This can be seen in the top two rows of Table 4. The tax advantage of holding bonds in a pension account rather than an ordinary investment account ranged between 15.2 percentage points and 15.9 percentage points under the four tax laws we examine. For those same four tax years the advantage of holding bonds in a pension account rather than a deferred annuity account ranged between 9.3 and 10.0 percentage points, or almost forty percent less than the pension tax advantage compared with holding bonds in a regular investment account. This calculation does not mean the pension tax advantage is small or economically insignificant, but it does imply that the OMB and JCT estimates of the pension tax expenditure considerably overstate the financial advantage to worker-savers of locating bond investments in a pension account. The estimated pension tax preference for holding bonds shown in Table 4 has declined very modestly since 1985.

A second lesson in Table 4 is that the value of the tax preference for holding equities in a pension account varies widely depending on how equity returns are paid out to investors. Different forms of equity return have received widely varying tax treatment over the past quarter century, and this has produced a wide variation in the value of the pension tax preference for savers who hold equities in their retirement savings accounts. Our estimates suggest that there was little change between 1985 and 2007 in the value of the pension tax preference for equities providing all investor returns in the form of capital gains income. However, the similarity of the tax preference in 1985 and 2007 disguises the fact that the value of the pension tax preference increased sharply between 1985 and 1988, when long-term capital gains income lost preferential treatment in the regular income tax code. The pension tax preference provided to dividendpaying stocks fell sharply between 1985 and 2007 primarily because qualified stock dividends received a generous tax preference in the regular tax code.

The third lesson of Table 4 is that the pension tax preference continues to be economically significant for the typical U.S. worker. Compared with accumulating retirement 
savings in either an ordinary investment account or a deferred annuity account, workers can expect to pay significantly lower taxes on gross earnings if they save inside a pension account. Even though the cumulative tax savings are typically smaller than they were in the mid-1980s, they are still substantial for most workers.

Finally, the results in Table 4 show that the financial advantage to accumulating savings in a pension account relative to some alternatives is considerably overstated in official tax expenditure estimates. As noted in section 2 above, OMB calculates tax expenditures for the pension tax preference under the assumption that the capital income flows received by pension savers would not receive any tax preference in the absence of the pension tax preference. Under current tax law, however, it would be foolish for workers to make the same assumption. Bond investments receive a sizeable tax preference if they are held inside of a deferred annuity account. Long-term capital gains and dividends receive a generous tax preference even without being held inside a deferred investment account. What matters for retirement savers is the net preference relative to alternatives that their savings receive if they are located inside a pension account. For this calculation to be meaningful, it must also reflect the tax preference the investment would receive if held in other kinds of investment accounts. The potential importance of alternative tax preferences is evident in Table 4. Compare, for example, the pension tax preferences on equity investment under the 1985 law. Under that law dividend income received no tax preference if equities were held in an ordinary investment account. Capital gains income, on the other hand, received a generous tax preference. Our calculations in Table 4 assume that all equity investments earn the same nominal return, 8\% per year. The calculations for 1985 show that the pension tax preference was more than 12 percentage points greater for all-dividend stocks compared with no-dividend stocks. Contrary to OMB's assumption, retirement savers can usually take advantage of other capital income tax preferences if they choose to accumulate savings outside of a tax-preferred pension account

Table 5 presents estimates of the pension tax preference for alternative assets using different population weights than the ones used in Table $4 .^{22}$ Instead of using weights derived from the entire population of 21-64 year-old workers, we derived weights for workers in this age group who were offered a pension at their place of work. Workers who are offered a workplace

22 The benefits of pension investment measured as changes in the real rate of return are displayed in Appendix Table 2. The estimates in that table are based on the same sample weights used to derive estimates in Table 5. 
pension tend to earn higher wages than people employed in workplaces without a pension. As a result, the pension tax preferences in Table 5 are larger than those displayed in Table 4. Equally important, the estimated drop in the value of the pension tax preference between 1985 and 2007 is greater in Table 5 than it is in Table 4. The results in Table 5 also highlight the importance of considering the tax preferences available to capital income when assets are held outside of pension accounts. When these tax preferences are included in the calculations, the value of the pension tax preference is highly sensitive to changes in other elements of tax law. Because the OMB and JCT estimates of tax expenditures assume that the worker would otherwise have paid tax at ordinary income rates, they fail to capture how the tax expenditure for pensions may have declined over time because of increases in tax preferences for equities held outside of pensions.

\section{Conclusion and extensions}

To encourage workers to save for retirement, the federal government offers favorable tax treatment on money that is withheld from wages and saved inside a pension plan. But the tax code also contains major tax preferences for assets held outside of pension accounts, and the value of these tax preferences has increased over time. To estimate accurately the net tax preference available to pension savers it is necessary to compare the taxes that would be paid or the net returns that would be earned if assets were held in a pension account rather than in an alternative kind of account. To the extent that assets held in alternative kinds of account receive a tax preference, the effect of that tax preference on the worker's taxes and on the worker's net return on retirement savings must also be taken into account.

In this paper we calculate the net value of the pension tax preference for representative workers under stylized assumptions about their future expected earnings and taxable incomes. We perform these calculations under tax laws in effect in 1985, 1988, 2000, and 2007, years when both the marginal tax rate schedule and the tax treatment of asset income differed. The basic tax preference for pension savings remained largely unchanged over the period, however. Workers were allowed to contribute to a pension account with pre-tax earnings, and their income on assets held inside the pension account was not subject to current income tax. Pension contributions and investment income were not taxed until workers made withdrawals from their pension accounts, usually in retirement. Although this tax preference can be valuable to retirement savers, its precise value is sensitive to the tax preference provided to capital income under the regular income tax code. Between 1985 and 2007 the most important tax changes 
affecting the value of the pension tax preference were connected to changes in the tax preference for equity income. The two biggest components of equity income, dividend payments and longterm capital gains, received varying tax treatment over the period. When one or both of these income components received more favorable tax treatment, the value of the pension tax preference fell. While it remained advantageous for workers to accumulate retirement savings in a pension account, the net tax advantage shrank. Official estimates of tax expenditures do not currently capture the effect of expanded preferences for capital income outside of qualified accounts on the cost of the preferences for retirement saving inside these accounts.

While we believe our analysis provides a realistic approximation of the value of the pension tax preference for representative workers, three extensions of the analysis would be worthwhile. First, we follow the Social Security Actuary in assuming that workers' age-earnings profiles will match the average profile of all Social-Security-covered workers. In addition, we assume that workers' taxable incomes will be predictable multiples of their family earnings. In fact, nearly all workers have a more erratic trajectory of wages and taxable income than implied by the average age-earnings profile. It would be useful to replicate our simulation using actual taxable income histories for a large and representative sample of workers. Second, our calculations focus on the tax preference for pensions in the federal income tax. State income taxes and FICA payroll taxes also affect the financial payoff to accumulating savings in a pension account. Employer contributions into a worker's pension account are typically excluded from wages subject to FICA payroll taxes as well as federal income taxes. Employee contributions into a 401(k) or 403(b) pension plan, in contrast, are excluded from federal taxable income but are included in wages subject to the Social Security and Medicare payroll tax. For most workers, the exclusion of pension contributions from the payroll tax base represents a net financial gain, though for workers with low or erratic wages this is less clear cut. In exchange for higher FICA payroll taxes, workers obtain higher monthly Social Security benefits after they retire. The tradeoff of higher payroll taxes for higher future Social Security benefits can be very advantageous for low-wage workers but often yields low or negative returns for average- and high-wage workers. The inclusion of payroll taxes in the analysis requires separate treatment of employer and employee pension contributions as well as a careful analysis of the effect of payroll tax contributions on future Social Security benefits. 
Finally, our analysis rests on the assumption that stock and bond returns are constant over workers' careers. This simplification probably has little effect on our estimate of the pension tax preference for investing in bonds. It may produce a serious distortion in our estimate of the tax preference for holding equities in a pension account, however. Expected stock returns have been higher than expected bond returns over long periods because a higher expected return is needed to compensate equity investors for the higher variability of stock returns. Most of the excess variation in stock returns arises because of fluctuations in equity prices. Variation in stock prices permits investors to manage their income tax liabilities on equity holdings through strategic realizations of capital gains and losses. One factor that affects the timing of gains and losses is the tax liability that would be incurred or avoided as a result of a realization. By assuming that capital gains are a stable and predictable component of equity income we have ignored investors' opportunities for deferring taxes through opportunistic realizations of gains and losses. It would be possible to estimate the value of the pension tax preference by simulating the historical pattern of stock market returns and modeling the capital gains realizations that would be taken by a strategic investor. It is unclear, however, whether a typical worker who holds stocks in a retirement portfolio would pursue a tax-optimizing capital gain realization strategy if that worker held equities outside a pension account. 


\section{References}

Bell, Felicitie C., and Michael L. Miller. 2005. Life Tables for the United States Social Security Area 1900-2100. Office of the Chief Actuary, Actuarial Study No. 120. Baltimore, MD: Social Security Administration.

Bergstresser, Daniel, and James Poterba. 2002. "Do After-tax Returns Affect Mutual Fund Inflows?” Journal of Financial Economics.63(3) (March): 381-414.

Board of Governors. Various issues. "Flow of Funds Accounts, Flows and Outstandings,” Z.1 statistical release. Washington, DC: Board of Governors of the Federal Reserve System.

Board of Trustees, Federal Old-Age and Survivors Insurance and Disability Insurance Trust Funds. 2009 Annual Report of the Board of Trustees, Federal Old-Age and Survivors Insurance and Disability Insurance Trust Funds. Washington, D.C.: Board of Trustees, Federal Old-Age and Survivors Insurance and Disability Insurance Trust Funds, 2009.

Bosworth, Barry P., Gary Burtless, and Eugene Steuerle. 2000. "Lifetime Earnings Patterns, the Distribution of Future Social Security Benefits, and the Impact of Pension Reform.” Social Security Bulletin, 63(4): 74-98.

Burman, Leonard E., William G. Gale, Matthew Hall, and Peter R. Orszag. 2004. "Distributional Effects of Defined Contribution Plans and Individual Retirement Arrangements.” National Tax Journal. 57(3) (September): 671-701.

Burtless, Gary. 2009. “Expanding Participation in America’s Workplace Retirement System,” in M. Orenstein, ed., Pensions, Social Security, and the Privatization of Risk. New York: Columbia University Press.

Clingman, Michael, and Orlo Nichols 2007. "Scaled Factors for Hypothetical Earnings Examples under the 2007 Trustees Report Assumptions,” Actuarial Note Number 2007.3 (September). Baltimore, MD: Social Security Administration, Office of the Chief Actuary.

Dammon, Robert M., Chester S. Spatt, and Harold H. Zhang. 2004. "Optimal Asset Location and Allocation with Taxable and Tax-deferred Investing." Journal of Finance 59(3) (June): 999-1037.

Favreault, Melissa, and Karen Smith. 2004. “A Primer on the Dynamic Simulation of Income Model (DYNASIM3).” The Retirement Project Discussion Paper 02-04. Washington, DC: Urban Institute.

Ghilarducci, Teresa. 2008. "The Changing Role of Employer Pensions: Tax Expenditures, Costs and Implications for Middle Class Elderly," in D.B. Papadimitriou, ed., Government Spending on the Elderly. Basingstoke, UK: Palgrave Macmillan.

. 2009 "Pension Reform in the United States: Guaranteed Pension Accounts Are Key.” Rotman International Journal of Pension Management. 2(2) (Fall): 58-65

Hungerford, Thomas L. 2006. Tax Expenditures: Trends and Critiques. (September) Washington: Congressional Research Service. 
Investment Company Institute. Various years. Investment Company Fact Book: A Review of Trends and Activity in the Investment Company Industry. Washington, DC: Investment Company Institute.

Joint Committee on Taxation, U.S. Congress. Various years. Estimates of Federal Tax Expenditures. Washington, DC: U.S. Government Printing Office.

Munnell, Alicia H. 1992. "Current Taxation of Qualified Pension Plans: Has the Time Come?” New England Economic Review (March/April): 12-25.

Poterba, James, John Shoven, and Clemens Sialm. 2001. "Asset Location for Retirement Savers," in W. Gale, J. Shoven, and M. Warshawsky, eds., Private Pensions and Public Policies. Washington, DC: Brookings Institution.

Rohaly, Jeff, Adam Carasso, and Mohammed Adeel Saleem. 2005. “The Urban-Brookings Tax Policy Center Microsimulation Model: Documentation and Methodology for Version 0304.” Washington, DC: Urban-Brookings Tax Policy Center.

Social Security Administration. 2009. Income of the Population 55 or Older, 2006. Baltimore, MD: Social Security Administration.

Tax Policy Center. 2009. "Estate Tax Returns and Liability Under Current Law and Various Reform Proposals.” Washington, DC: Urban-Brookings Tax Policy Center. URL: http://taxpolicycenter.org/numbers/displayatab.cfm?Docid=2475

Toder, Eric J., Benjamin H. Harris and Katherine Lim. 2009. "Distributional Effects of Tax Expenditures.” Working Paper. Tax Policy Center and Schwartz Center for Economic Policy, New School for Social Research. Washington, DC: Urban-Brookings Tax Policy Center.

U.S. Internal Revenue Service. 2009. Publication 575 - Pension and Annuity Income. Washington, DC: U.S. Internal Revenue Service.

U.S. Office of Management and Budget. 2009. Budget of the US Government: Analytical Perspectives, Fiscal Year 2010. Washington: US Government Printing Office. 
Table 1. Asset Allocation of Investments Held in IRAs and Public and Private Pension Funds, 2006-2008 $\underline{1}$ /

Percent of total assets

\begin{tabular}{rrrrr}
\hline & $\mathbf{2 0 0 6}$ & $\mathbf{2 0 0 7}$ & $\mathbf{2 0 0 8}$ & 2006-2008 average \\
\hline \hline Bonds or other interest-bearing assets & 26 & 26 & 37 & 30 \\
Equities of U.S. and foreign companies & 67 & 66 & 53 & 62 \\
Insurance contracts & 6 & 6 & 7 & 6 \\
Real estate and "other" & 2 & 2 & 3 & 2 \\
\hline
\end{tabular}

$\underline{1}$ / Asset allocations in the fourth quarter. Estimates exclude assets that back federal employee pensions.

Source: Authors' calculations based on Board of Governors (various issues) and Investment Company Institute (various years). 
Table 2. Tax Increase If Worker Locates Saving in Ordinary Investment Account or Insurance Plan Rather than a Pension Account: Rate Increases under Alternative Tax Laws and Worker Contribution Ages (Lump-Sum Distribution) $\underline{1} /$

\begin{tabular}{|c|c|c|c|c|c|}
\hline \multirow{2}{*}{$\begin{array}{l}\text { Age at time of } \\
\text { contribution }\end{array}$} & \multicolumn{4}{|c|}{ Calendar year of contribution } & \multirow{2}{*}{$\begin{array}{c}\text { Change, } \\
1985 \text { to } 2007\end{array}$} \\
\hline & 1985 & 1988 & 2000 & 2007 & \\
\hline \multicolumn{6}{|l|}{ Bonds } \\
\hline 29 & 33 & 27 & 27 & 26 & -7 \\
\hline 39 & 29 & 21 & 21 & 19 & -10 \\
\hline 49 & 21 & 13 & 13 & 12 & -9 \\
\hline 59 & 7 & 5 & 5 & 4 & -3 \\
\hline
\end{tabular}

Insurance contract: Bond holdings

$\begin{array}{rrrrrr}\mathbf{2 9} & 18 & 17 & 17 & 15 & -2 \\ \mathbf{3 9} & 20 & 14 & 14 & 13 & -7 \\ \mathbf{4 9} & 17 & 10 & 10 & 10 & -7 \\ \mathbf{5 9} & 7 & 4 & 4 & 4 & -3\end{array}$

Equities: No dividends / All capital gains

$\begin{array}{rrrrrr}\mathbf{2 9} & 15 & 26 & 19 & 15 & 1 \\ \mathbf{3 9} & 17 & 22 & 16 & 13 & -4 \\ \mathbf{4 9} & 14 & 16 & 11 & 9 & -5 \\ \mathbf{5 9} & 5 & 7 & 5 & 4 & -2\end{array}$

Equities: $2.5 \%$ Dividend

$\begin{array}{rrrrrr}\mathbf{2 9} & 26 & 30 & 26 & 18 & -7 \\ \mathbf{3 9} & 24 & 24 & 21 & 14 & -10 \\ \mathbf{4 9} & 19 & 17 & 14 & 10 & -9 \\ \mathbf{5 9} & 7 & 7 & 6 & 4 & -3\end{array}$

Equities: All dividends / No capital gains

$\begin{array}{rrrrrr}\mathbf{2 9} & 44 & 35 & 41 & 21 & -24 \\ \mathbf{3 9} & 38 & 29 & 29 & 18 & -20 \\ \mathbf{4 9} & 27 & 19 & 19 & 12 & -16 \\ \mathbf{5 9} & 10 & 7 & 7 & 4 & -6\end{array}$

1/ The calculations refer to a married worker who earns a medium lifetime wage and is married to a spouse who earns twice the medium wage. Both spouses are the same age and expect to retire and claim a Social Security benefit at age 65. All money in the investment account, after payment of taxes, is consumed immediately after retirement at age 65 (see text).

Source: Authors' tabulations as described in text. 
Table 3. Tax Increase If Worker Locates Saving in Ordinary Investment Account or Insurance Plan Rather than a Pension Account: Rate Increases under Alternative Tax Laws and Worker Contribution Ages (Annuity Distribution) $\underline{1} /$

\begin{tabular}{|c|c|c|c|c|c|}
\hline \multirow{2}{*}{$\begin{array}{c}\text { Age at time of } \\
\text { contribution }\end{array}$} & \multicolumn{4}{|c|}{ Calendar year of contribution } & \multirow{2}{*}{$\begin{array}{c}\text { Change, } \\
1985 \text { to } 2007\end{array}$} \\
\hline & 1985 & 1988 & 2000 & 2007 & \\
\hline \multicolumn{6}{|l|}{ Bonds } \\
\hline 29 & 41 & 38 & 37 & 35 & -5 \\
\hline 39 & 37 & 32 & 31 & 30 & -8 \\
\hline 49 & 30 & 25 & 24 & 23 & -7 \\
\hline 59 & 18 & 17 & 17 & 16 & -2 \\
\hline
\end{tabular}

Insurance contract: Bond holdings

$\begin{array}{llllll}\mathbf{2 9} & 21 & 20 & 20 & 19 & -2 \\ \mathbf{3 9} & 24 & 19 & 19 & 18 & -6 \\ \mathbf{4 9} & 22 & 18 & 17 & 16 & -6 \\ \mathbf{5 9} & 16 & 15 & 15 & 14 & -2\end{array}$

Equities: No dividends / All capital gains

$\begin{array}{llllll}\mathbf{2 9} & 24 & 37 & 30 & 26 & 2 \\ \mathbf{3 9} & 26 & 33 & 27 & 23 & -3 \\ \mathbf{4 9} & 24 & 28 & 23 & 20 & -4 \\ \mathbf{5 9} & 16 & 19 & 17 & 15 & -1\end{array}$

Equities: 2.5\% Dividend

$\begin{array}{llllll}\mathbf{2 9} & 35 & 40 & 36 & 29 & -6 \\ \mathbf{3 9} & 33 & 35 & 31 & 25 & -8 \\ \mathbf{4 9} & 28 & 29 & 25 & 21 & -7 \\ \mathbf{5 9} & 17 & 19 & 18 & 15 & -2\end{array}$

Equities: All dividends / No capital gains

$\begin{array}{lllllr}\mathbf{2 9} & 51 & 45 & 49 & 31 & -21 \\ \mathbf{3 9} & 45 & 40 & 39 & 29 & -17 \\ \mathbf{4 9} & 36 & 31 & 30 & 22 & -14 \\ \mathbf{5 9} & 20 & 20 & 19 & 16 & -4\end{array}$

$\underline{1 /}$ The calculations refer to a married worker who earns a medium lifetime wage and is married to a spouse who earns twice the medium wage. Both spouses are the same age and expect to retire and claim a Social Security benefit at age 65. All money in the investment account, after payment of applicable taxes, is converted into a level, joint survivor annuity at age 65 (see text).

Source: Authors' tabulations as described in text. 
Table 4. Weighted Tax Increase If Workers Locate Saving in Ordinary Investment Account or Insurance Plan Rather than a Pension Account: Rate Increases under Alternative Tax Laws $\underline{1}$ /

Percentage points

\begin{tabular}{|c|c|c|c|c|c|}
\hline \multirow[b]{2}{*}{ Asset } & \multicolumn{4}{|c|}{ Calendar year of contribution } & \multirow{2}{*}{$\begin{array}{l}\text { Change, } \\
1985 \text { to } 2007\end{array}$} \\
\hline & 1985 & 1988 & 2000 & 2007 & \\
\hline & \multicolumn{5}{|c|}{ Account savings consumed at age 65} \\
\hline \multicolumn{6}{|l|}{ Bonds } \\
\hline Held in ordinary investment account & 15.9 & 15.8 & 15.7 & 15.2 & -0.7 \\
\hline Held inside insurance contract & 9.6 & 10.0 & 9.9 & 9.3 & -0.3 \\
\hline \multicolumn{6}{|l|}{ Equities } \\
\hline No dividends / All capital gains & 8.4 & 15.6 & 11.4 & 8.1 & -0.3 \\
\hline $2.5 \%$ Dividend & 12.9 & 17.8 & 15.1 & 9.4 & -3.6 \\
\hline All dividends / No capital gains & 21.3 & 22.3 & 22.3 & 12.0 & -9.3 \\
\hline & \multicolumn{5}{|c|}{ Account savings converted into an annuity at age 65} \\
\hline \multicolumn{6}{|l|}{ Bonds } \\
\hline Held in ordinary investment account & 20.5 & 22.3 & 22.6 & 20.3 & -0.2 \\
\hline Held inside insurance contract & 12.1 & 13.2 & 13.4 & 11.7 & -0.4 \\
\hline \multicolumn{6}{|l|}{ Equities } \\
\hline No dividends / All capital gains & 13.6 & 22.1 & 18.5 & 13.7 & 0.1 \\
\hline $2.5 \%$ Dividend & 17.8 & 24.1 & 22.0 & 14.8 & -2.9 \\
\hline All dividends / No capital gains & 25.6 & 28.3 & 28.7 & 17.3 & -8.3 \\
\hline
\end{tabular}

$\underline{1 /}$ Population weights reflect all persons with positive labor earnings in 2007. See text.

Source: Authors' tabulations as described in text. 


\section{Table 5. Weighted Tax Increase If Workers Locate Saving in Ordinary Investment Account or Insurance Plan Rather than a Pension Account: Rate Increases under Alternative Tax Laws $\underline{1}$ /}

Percentage points

\begin{tabular}{|c|c|c|c|c|c|}
\hline \multirow[b]{2}{*}{ Asset } & \multicolumn{4}{|c|}{ Calendar year of contribution } & \multirow{2}{*}{$\begin{array}{c}\text { Change, } \\
1985 \text { to } 2007 \\
\end{array}$} \\
\hline & 1985 & 1988 & 2000 & 2007 & \\
\hline & \multicolumn{5}{|c|}{ Account savings consumed at age 65} \\
\hline \multicolumn{6}{|l|}{ Bonds } \\
\hline Held in ordinary investment account & 18.0 & 16.5 & 16.1 & 15.8 & -2.2 \\
\hline Held inside insurance contract & 12.0 & 11.1 & 11.0 & 10.4 & -1.6 \\
\hline \multicolumn{6}{|l|}{ Equities } \\
\hline No dividends / All capital gains & 10.1 & 16.6 & 12.4 & 9.2 & -0.9 \\
\hline $2.5 \%$ Dividend & 15.0 & 18.6 & 15.9 & 10.5 & -4.4 \\
\hline All dividends / No capital gains & 24.0 & 22.6 & 22.5 & 13.2 & -10.8 \\
\hline & \multicolumn{5}{|c|}{ Account savings converted into an annuity at age 65} \\
\hline \multicolumn{6}{|l|}{ Bonds } \\
\hline Held in ordinary investment account & 24.3 & 23.5 & 23.8 & 21.4 & -2.9 \\
\hline Held inside insurance contract & 15.6 & 14.9 & 15.2 & 13.4 & -2.2 \\
\hline \multicolumn{6}{|l|}{ Equities } \\
\hline No dividends / All capital gains & 17.0 & 23.5 & 20.4 & 15.3 & -1.7 \\
\hline 2.5\% Dividend & 21.5 & 25.4 & 23.6 & 16.5 & -5.0 \\
\hline All dividends / No capital gains & 29.8 & 29.2 & 29.7 & 19.0 & -10.8 \\
\hline
\end{tabular}

1/ Population weights reflect all persons who have positive labor earnings and are offered a workplace pension plan in 2007. See text.

Source: Authors' tabulations as described in text. 
Figure 1. Estimates of Total Income Tax Expenditures for Net Exclusion of Pension Contributions and Earnings, Fiscal Years 1975-2008

\section{Percent of GDP}

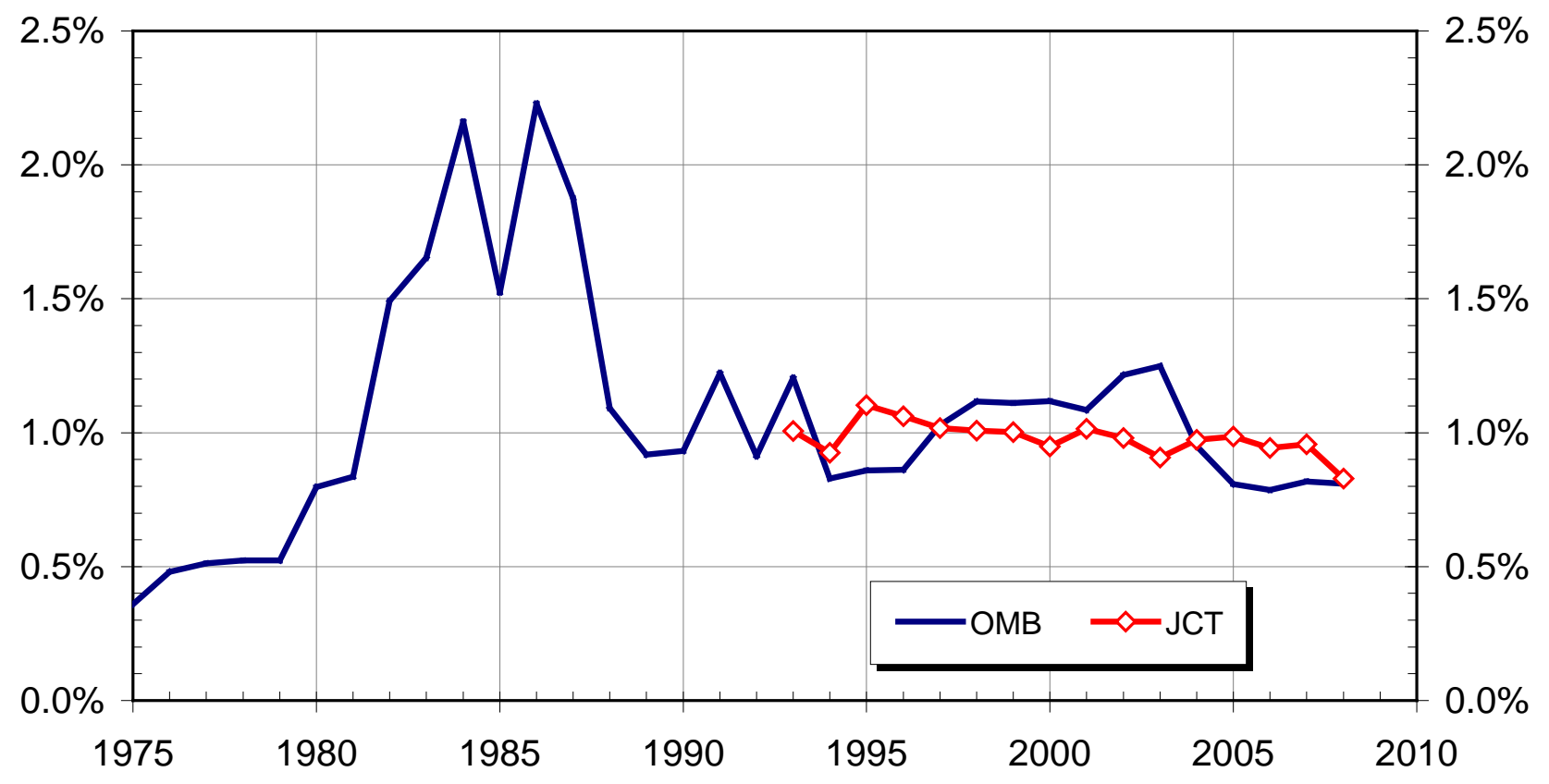

Source: U.S. Office of Management and Budget, Budget of the United States Government (various years); and U.S. Congress, Joint Committee on Taxation, Estimates of Federal Tax Expenditures (various years). 
Figure 2. Lifetime Earnings Profiles for Representative Workers with High, Medium, Low, and Very Low Career Earnings

Economy-wide average wage at indicated age $=\mathbf{1 . 0 0}$

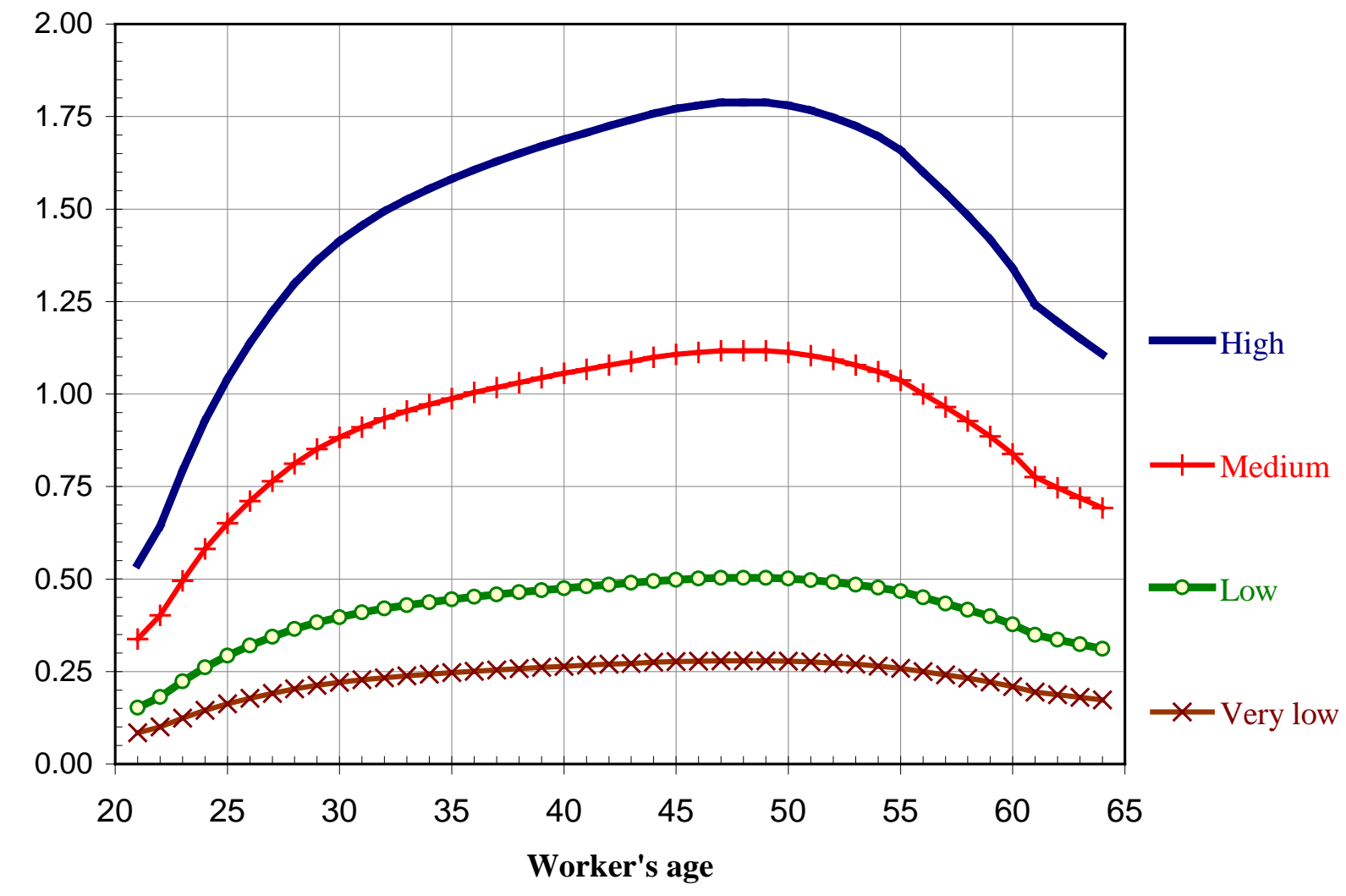

Source: Office of the Chief Actuary, Social Security Administration; Clingman and Nichols (2007). 
Figure 3. Cumulative Tax on Earned Income Invested in Alternative Types of Investment Account under 1985 Tax Law, by Age at Time of Contribution: Fund Withdrawal at Age $65 \underline{1 /}$

Cumulative tax on contribution (\%)

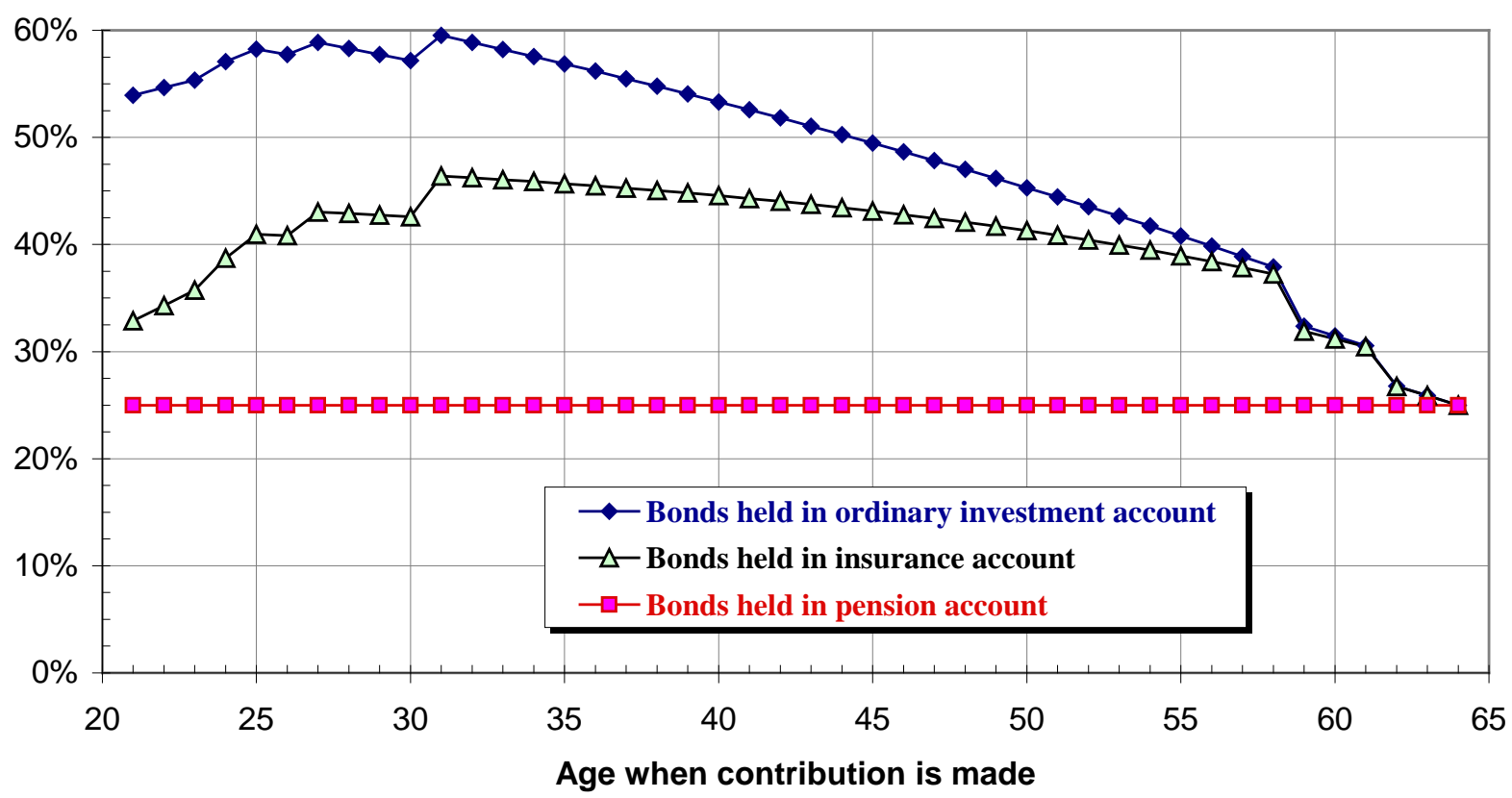

Change in tax rate as a result of investing in pension account (\%)

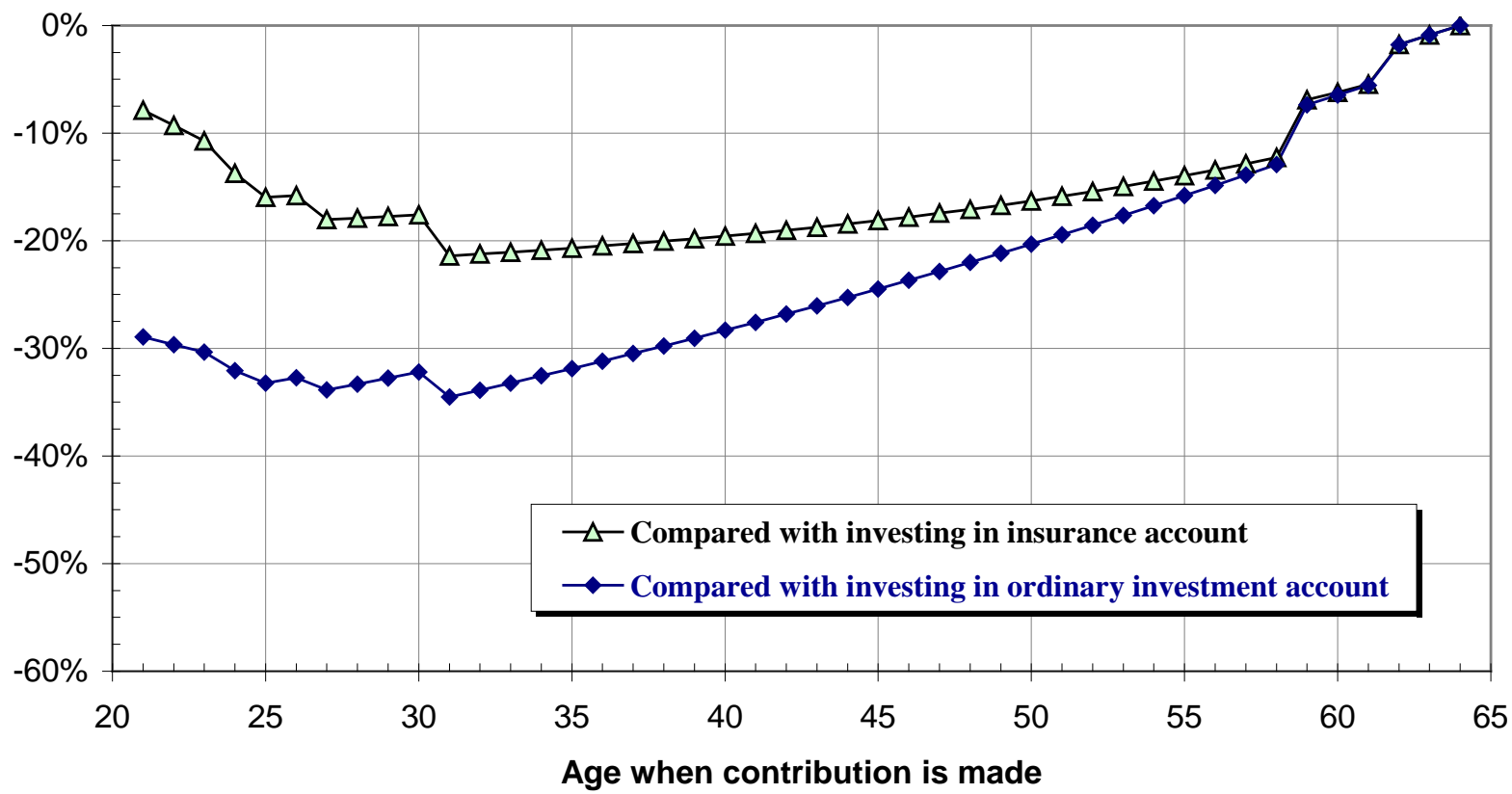

$\underline{1 /}$ The calculations refer to a married worker who earns a medium lifetime wage and is married to a spouse who earns twice the medium wage. See text. 
Figure 4. Cumulative Tax on Earned Income Invested in Alternative Types of Investment Account under 1985 Tax Law, by Age at Time of Contribution: Fund Withdrawal through a Joint Survivor Annuity $\underline{1 /}$

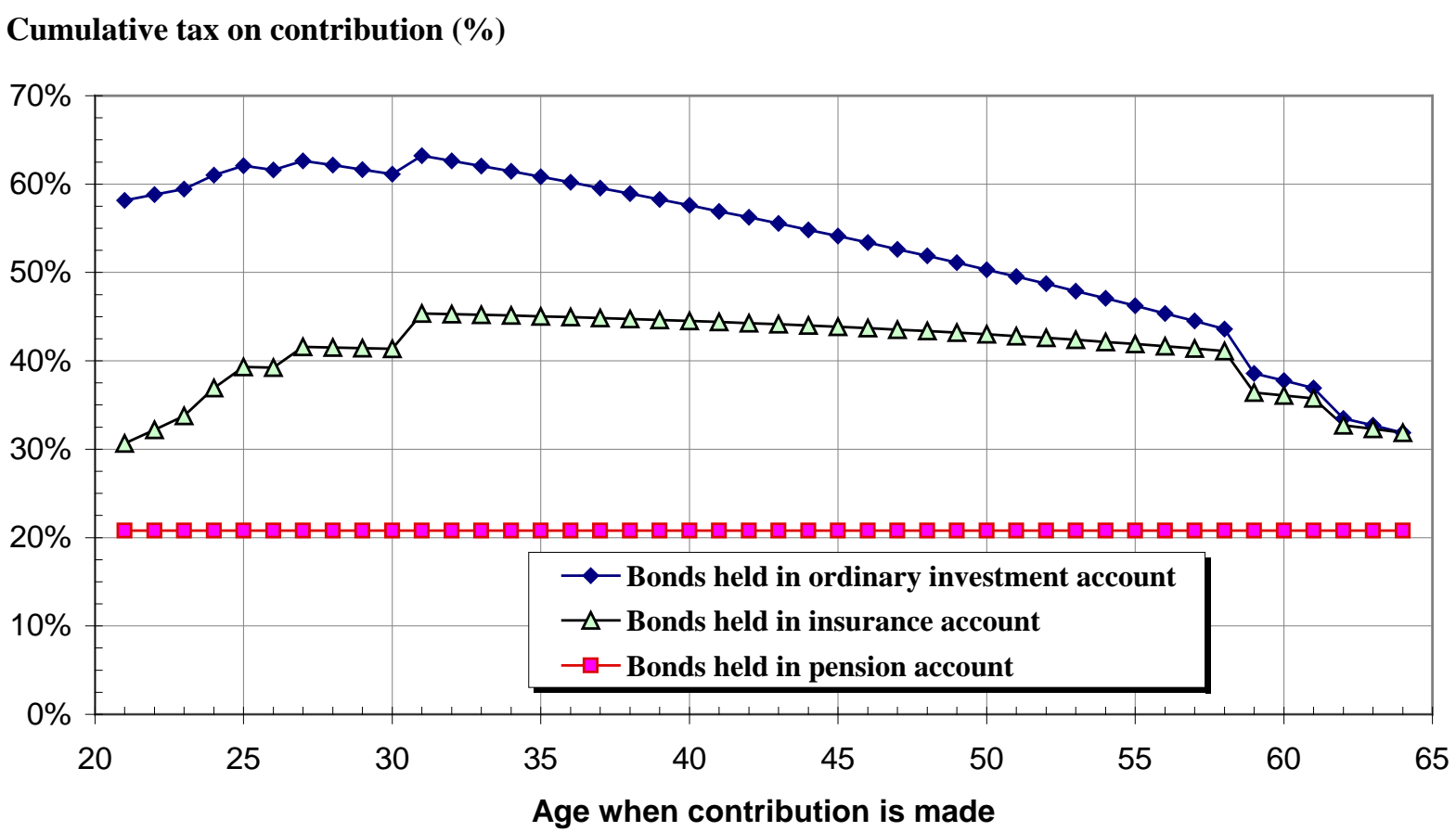

Change in tax rate as a result of investing in pension account (\%)

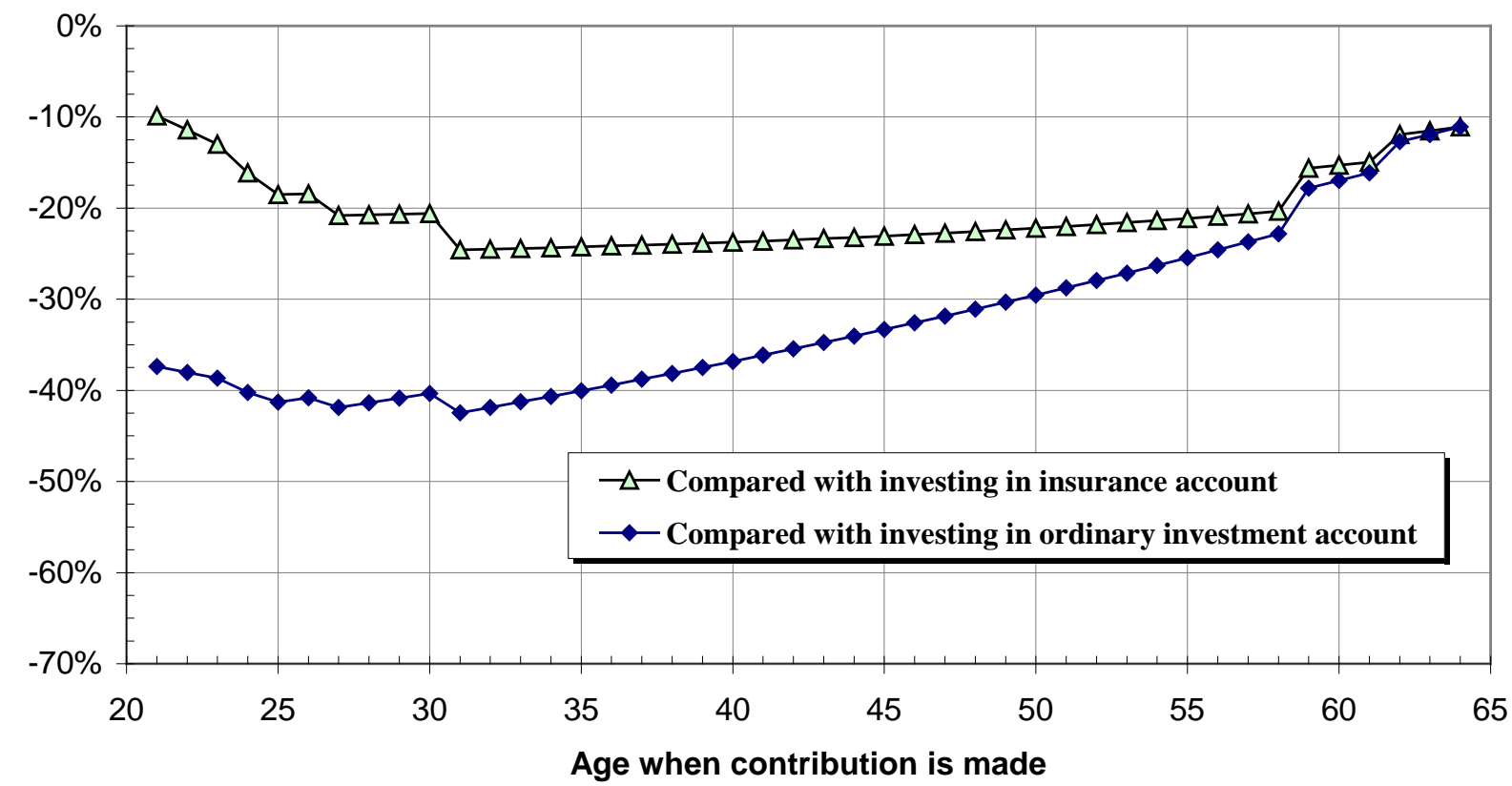

$\underline{1}$ / The calculations refer to a married worker who earns a medium lifetime wage and is married to a spouse who earns twice the medium wage. See text. 
Figure 5. Real Internal Rate of Return on Funds Invested in Alternative Types of Investment Account under 1985 Tax Law, by Age at Time of Contribution: Fund Withdrawal through a Joint Survivor Annuity $\underline{1}$ /

Real IRR on post-tax value of initial contribution (\%)

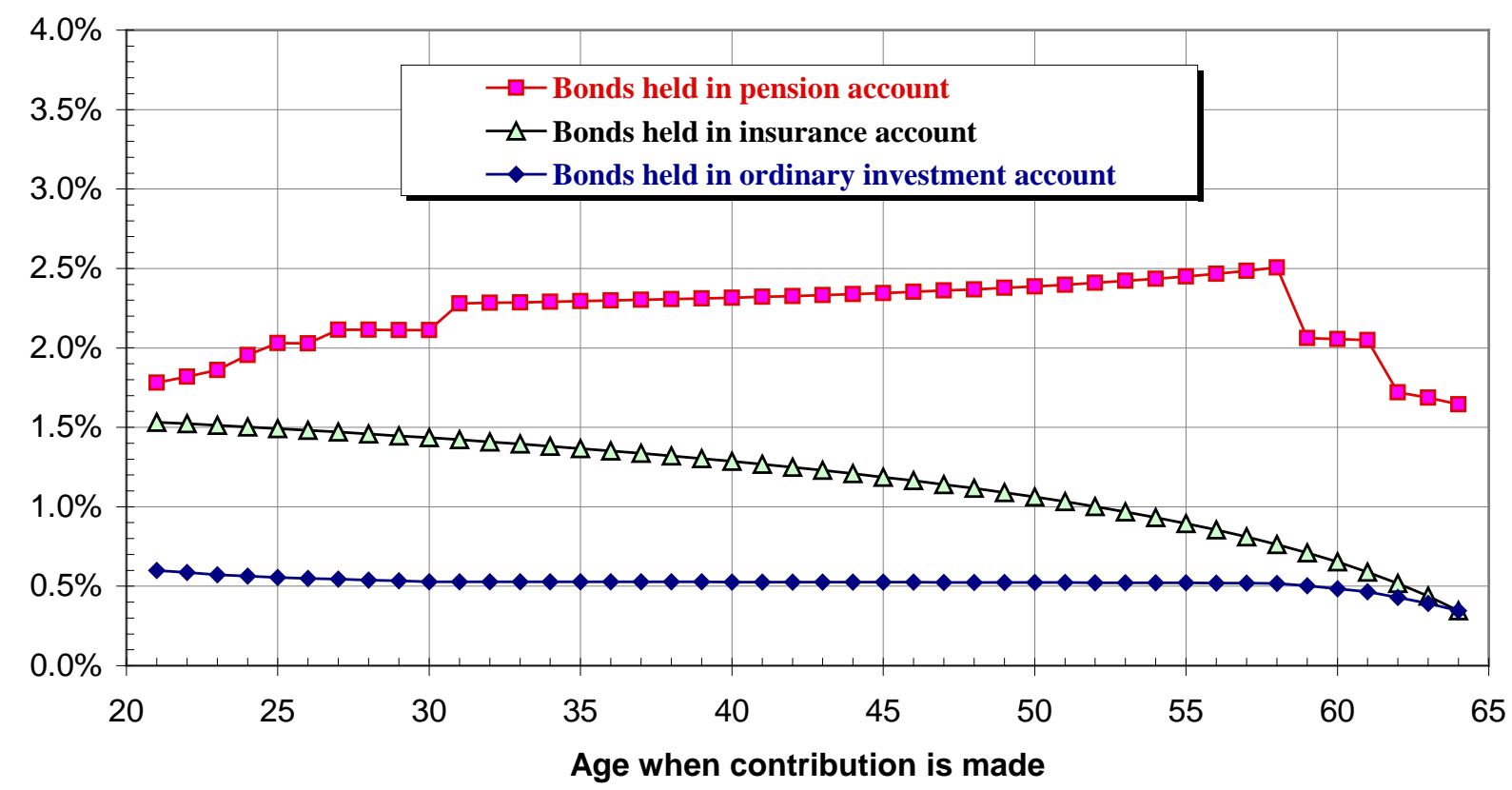

Change in real IRR as a result of investing in pension account (\%)

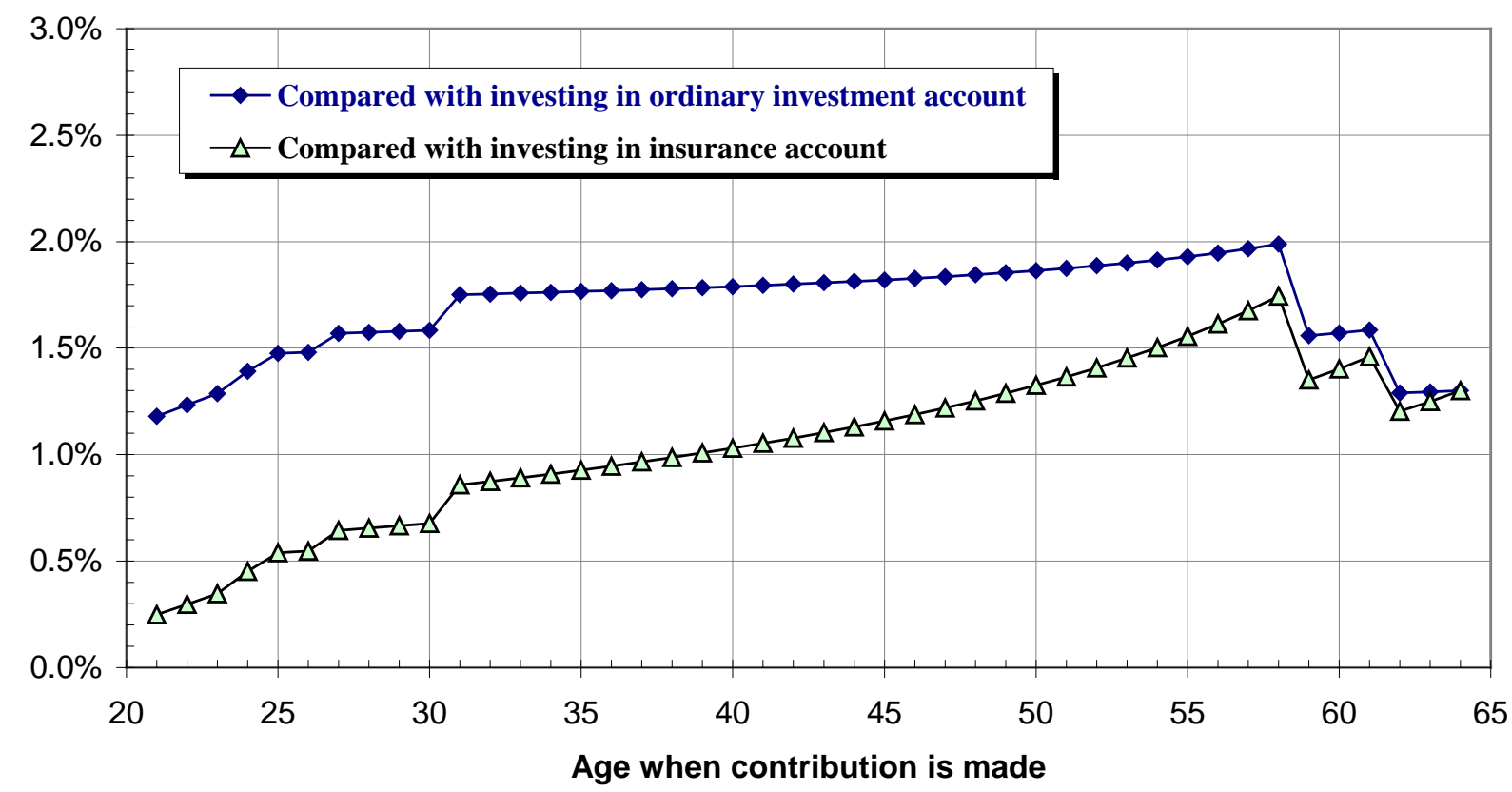

$\underline{1 /}$ The calculations refer to a married worker who earns a medium lifetime wage and is married to a spouse who earns twice the medium wage. See text. 
Figure 6. Cumulative Tax on Earned Income Invested in Equities in Alternative Types of Account under 1985 Tax Law, by Age at Time of Contribution: Fund Withdrawal through a Joint Survivor Annuity $\underline{1}$ /

Cumulative tax on contribution (\%)

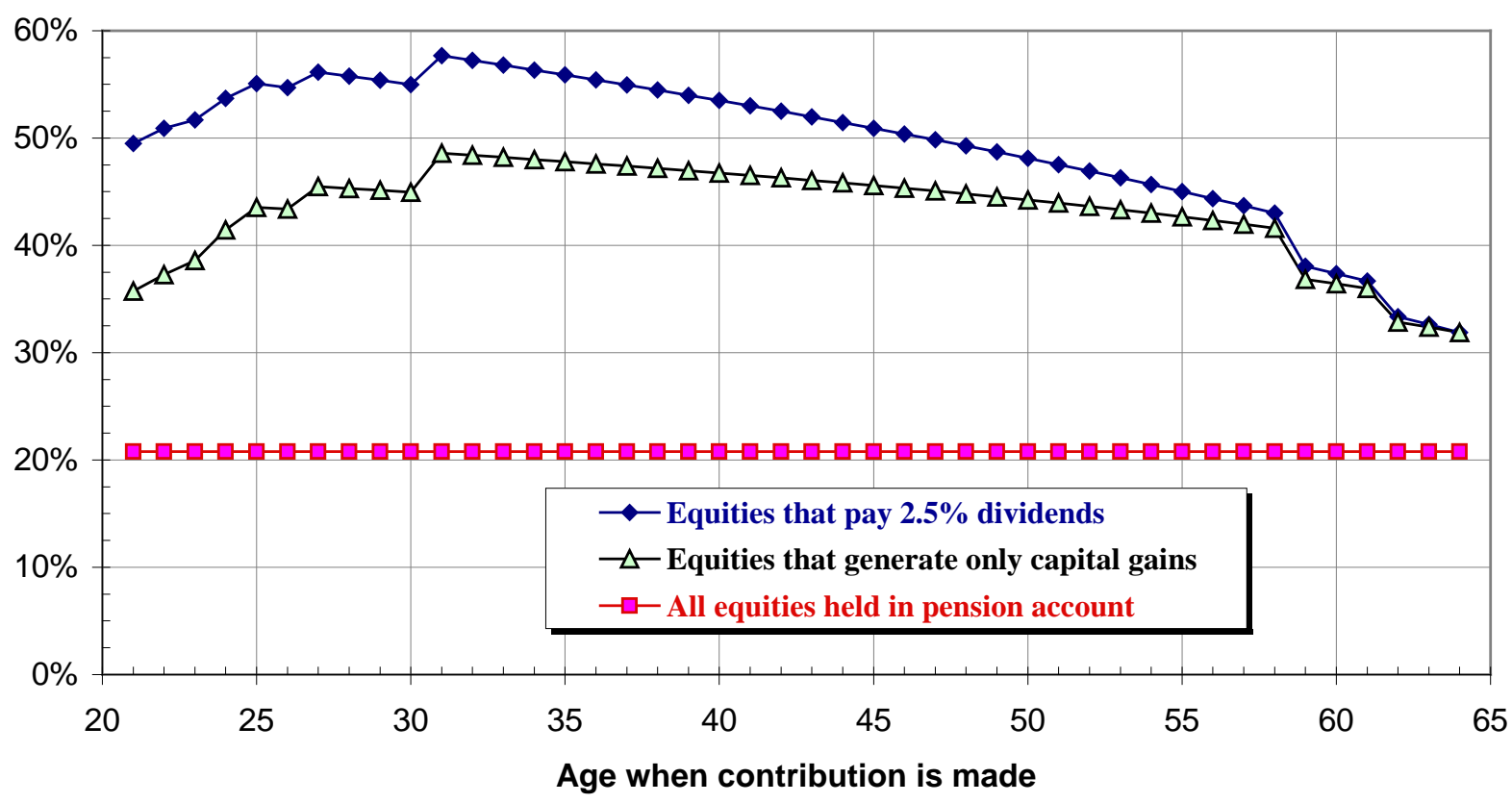

Change in tax rate as a result of investing in pension account (\%)

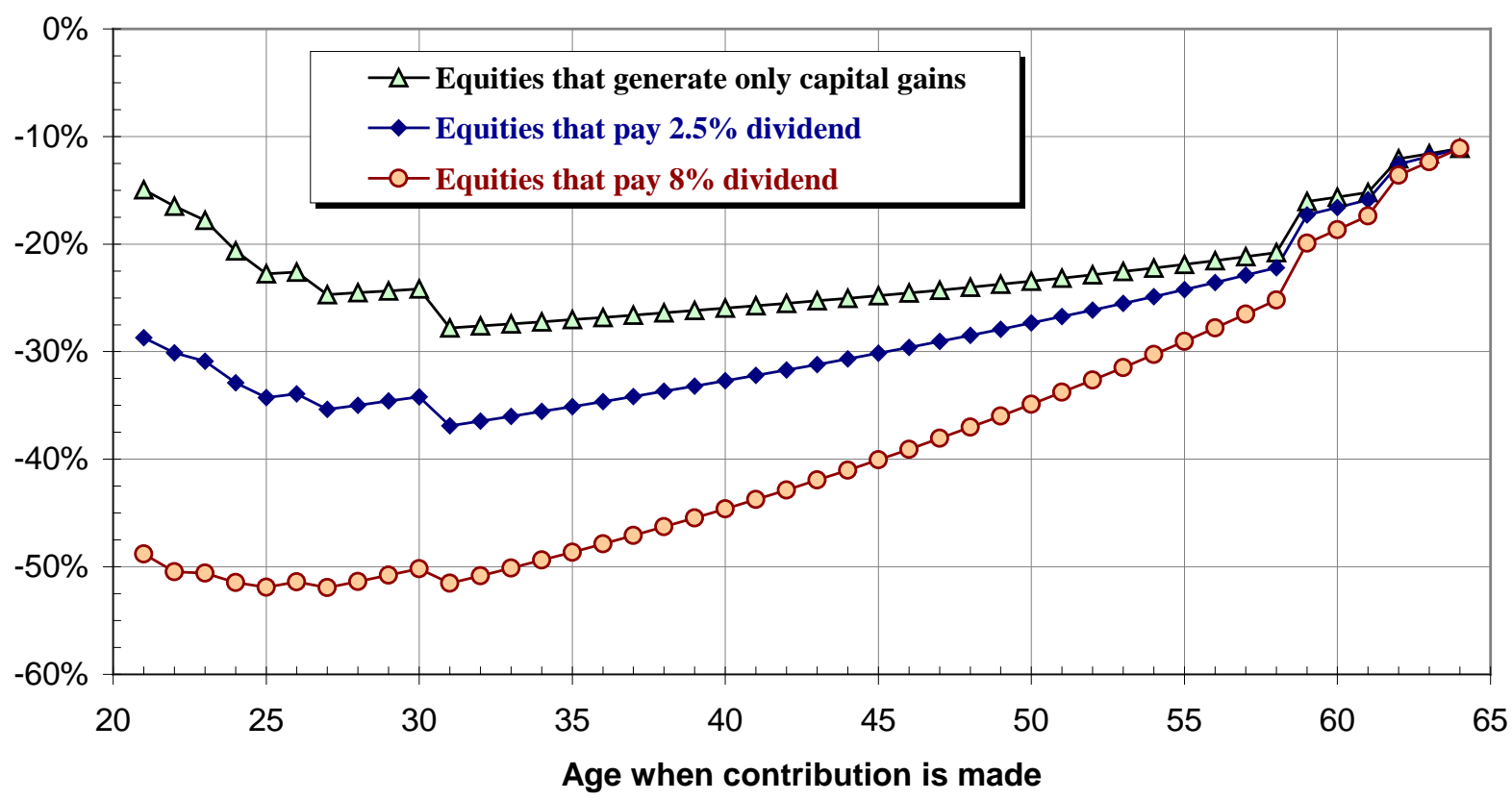

$\underline{1 /}$ The calculations refer to a married worker who earns a medium lifetime wage and is married to a spouse who earns twice the medium wage. See text. 
Figure 7. Tax Increase If Worker Locates Saving in Ordinary Investment Account Rather than Pension Account under 1985 Tax Law, by Earnings Level and Age of Contribution $\underline{1} /$

Percentage point tax increase: Investment in bonds

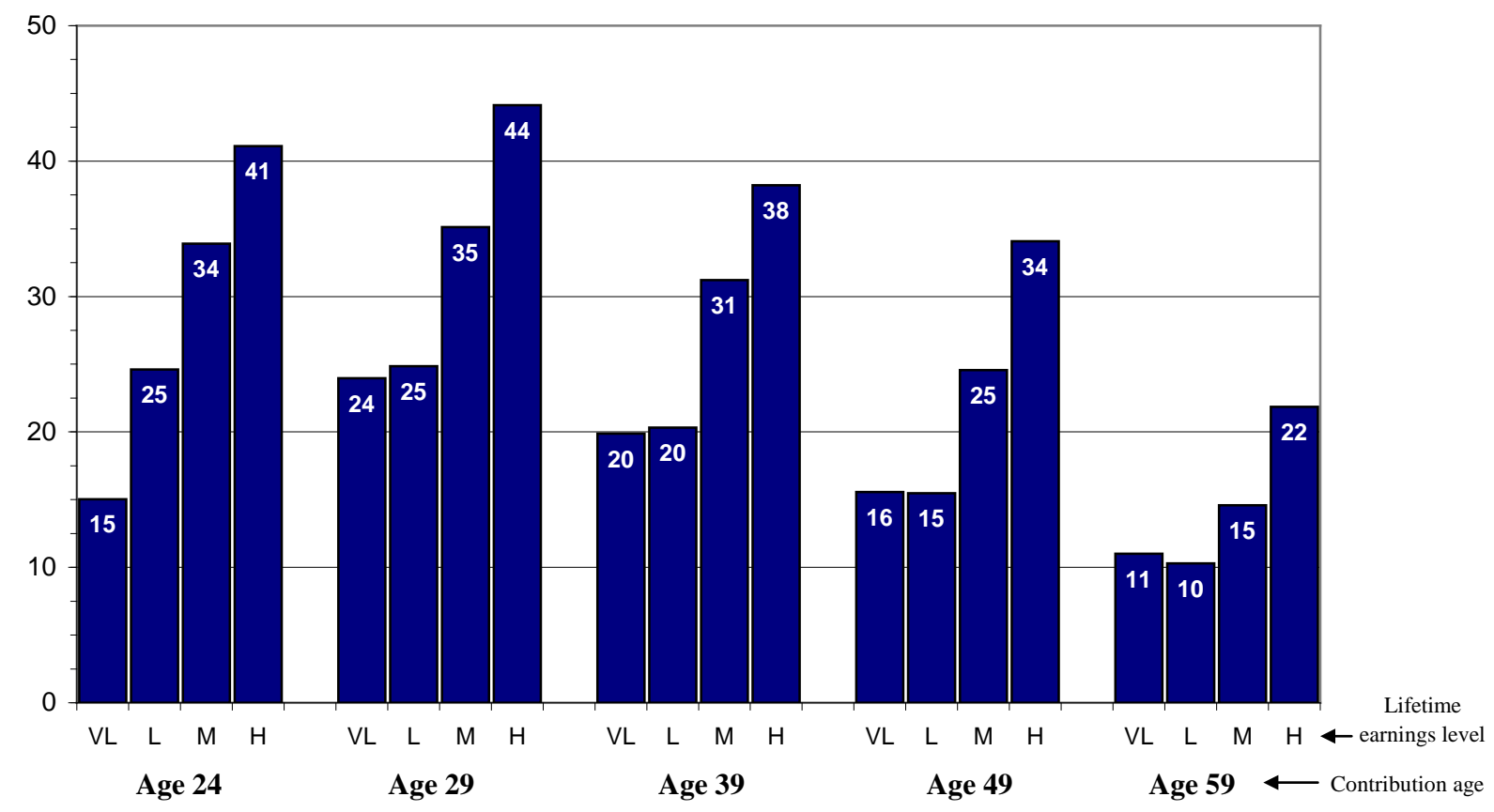

Percentage point tax increase: $\underline{\text { Investment in all-capital-gain stocks }}$

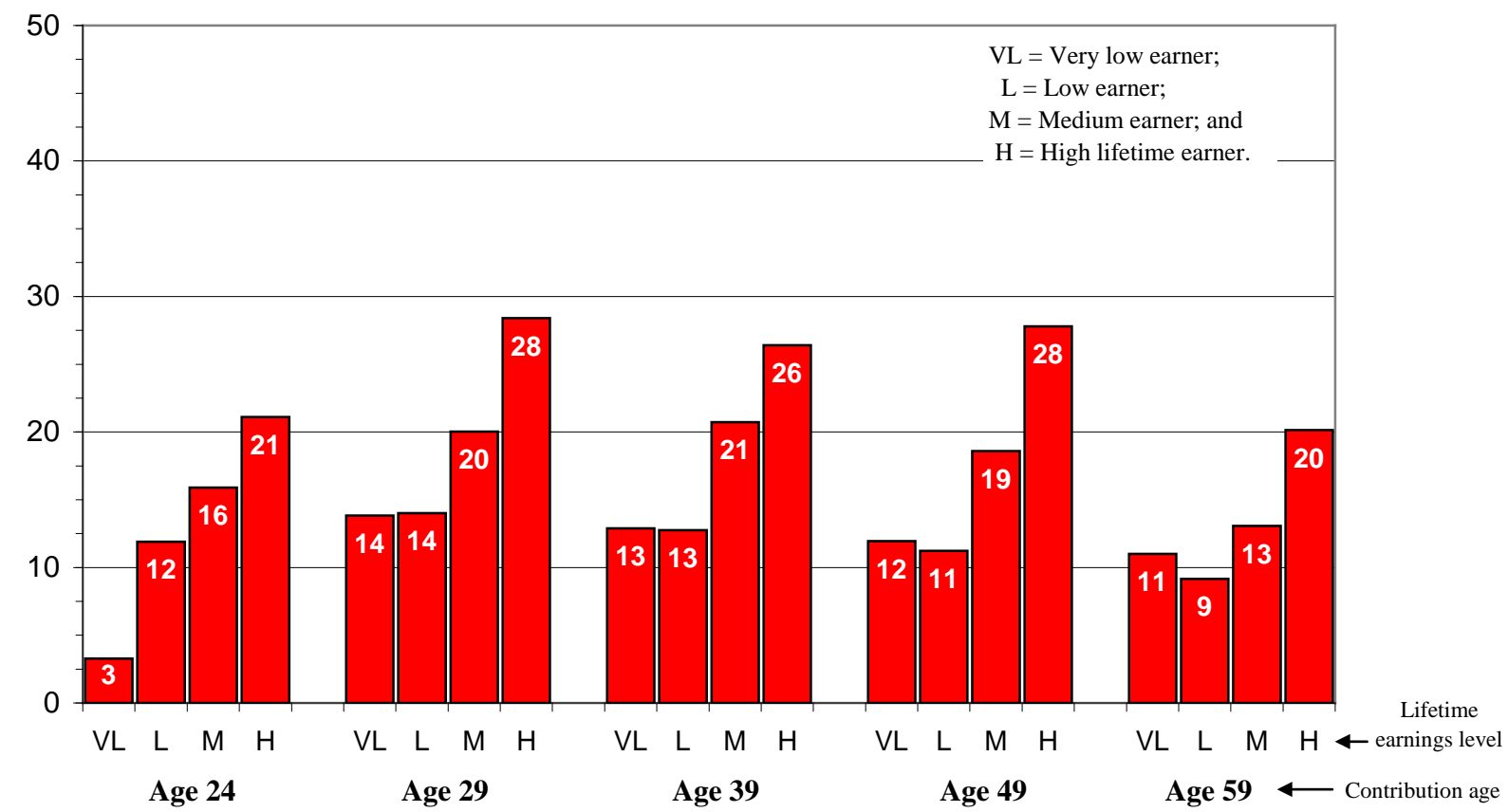

$\underline{1}$ / The calculations refer to a married worker whose spouse earns the same wage. Savings accumulated in the investment account are converted to a level, joint survivor annuity at age 65 . See text for additional details. 
Figure 8. Tax Increase If Saver Locates Saving in Ordinary Investment or Insurance Account Rather than Pension Account under Four Tax Laws, by Earnings Level

Tax increase on gross earnings (\%):

Bonds held in ordinary investment account

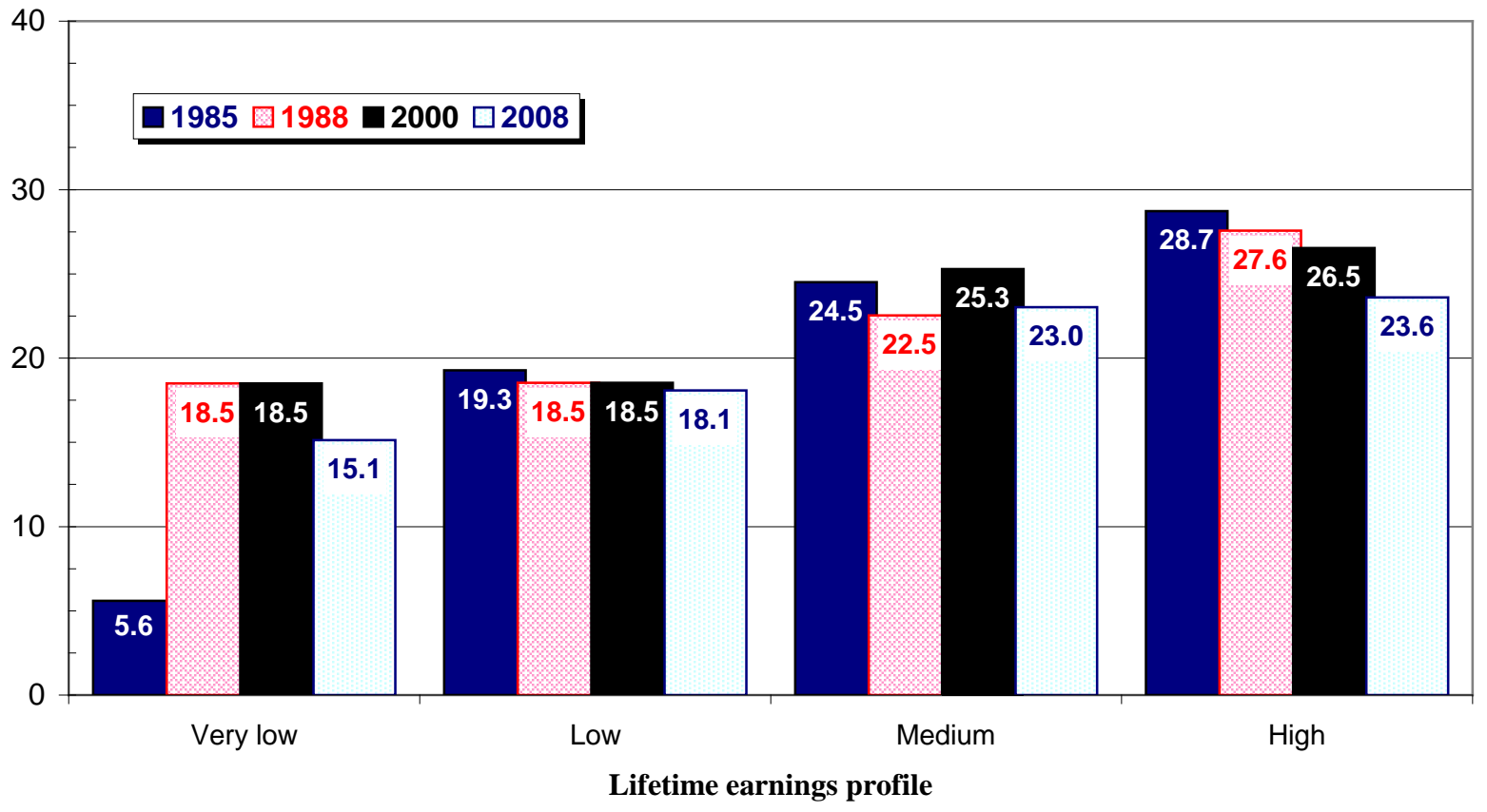

Tax increase on gross earnings (\%):

Bonds held inside an insurance policy

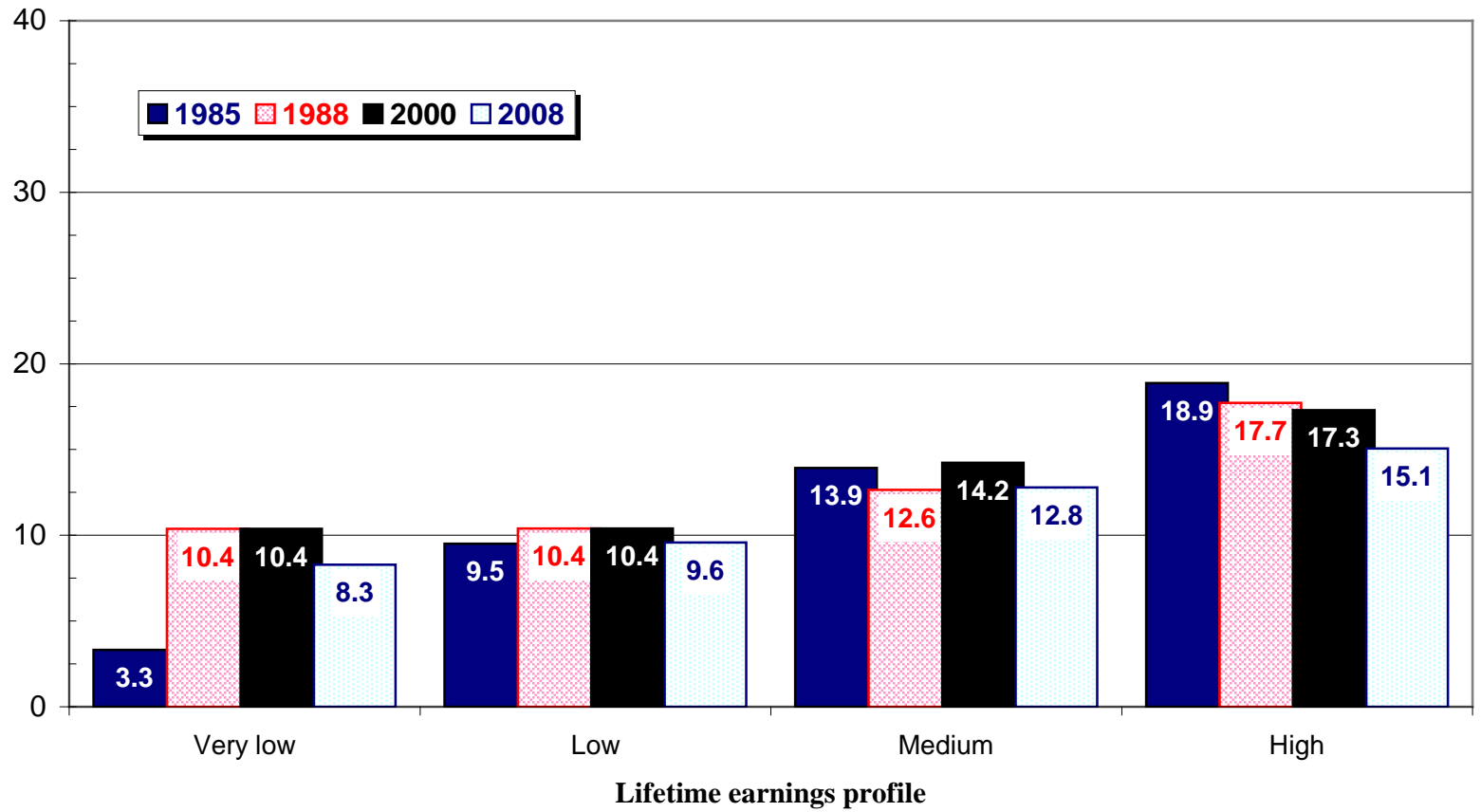

Source: Authors' estimates as explained in text. 
Figure 9. Tax Increase If Saver Locates Equity Investment in Ordinary Investment Account Rather than Pension Account under Four Tax Laws, by Earnings Level

Tax increase on gross earnings (\%):

Equities that pay no dividends

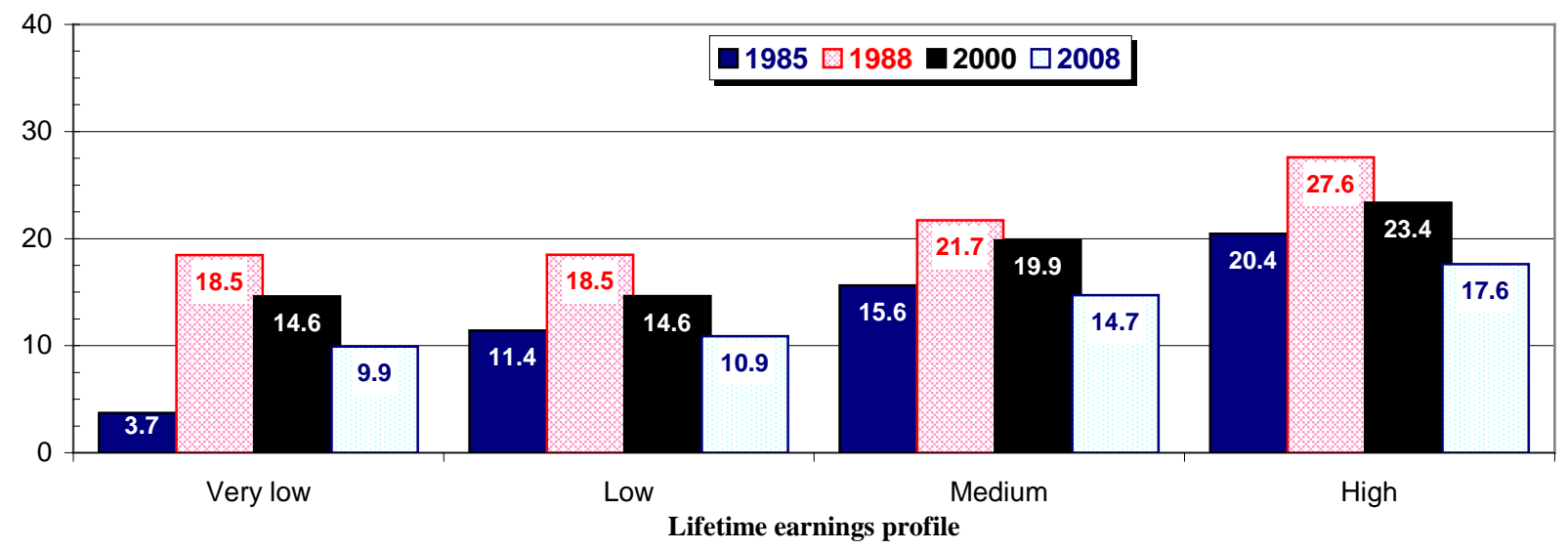

Tax increase on gross earnings (\%):

Equites that pay $2.5 \%$ dividends

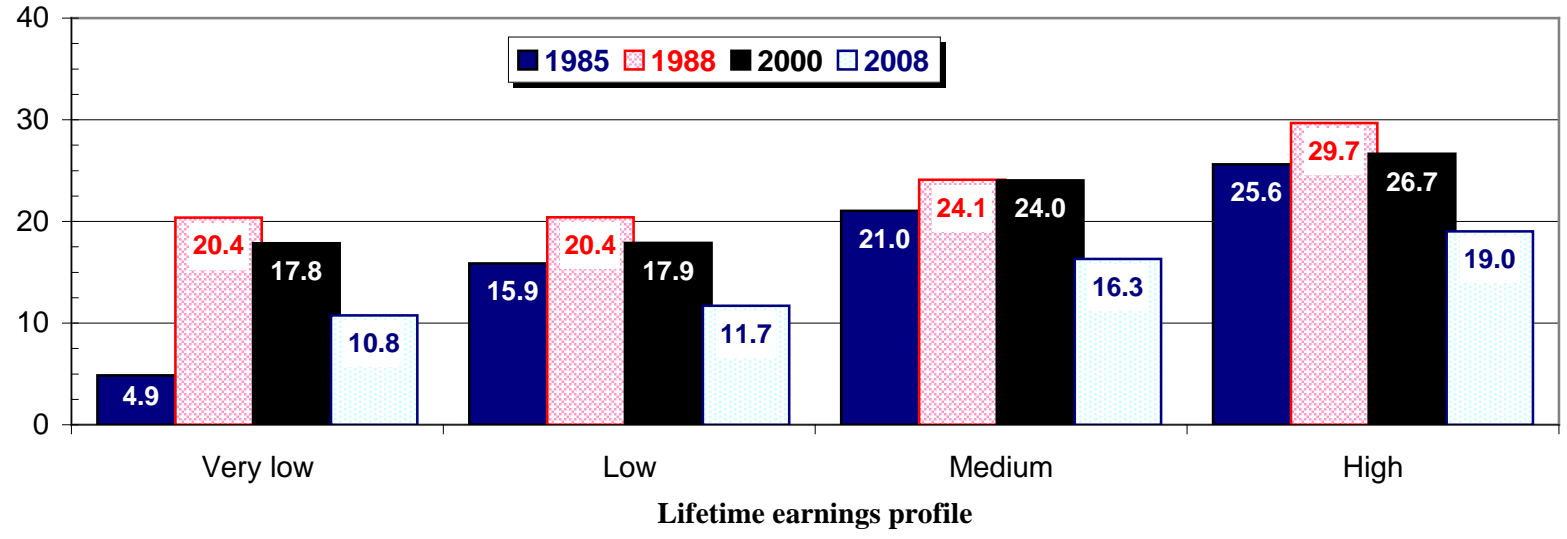

Tax increase on gross earnings (\%):

Equities that pay $8.0 \%$ dividends

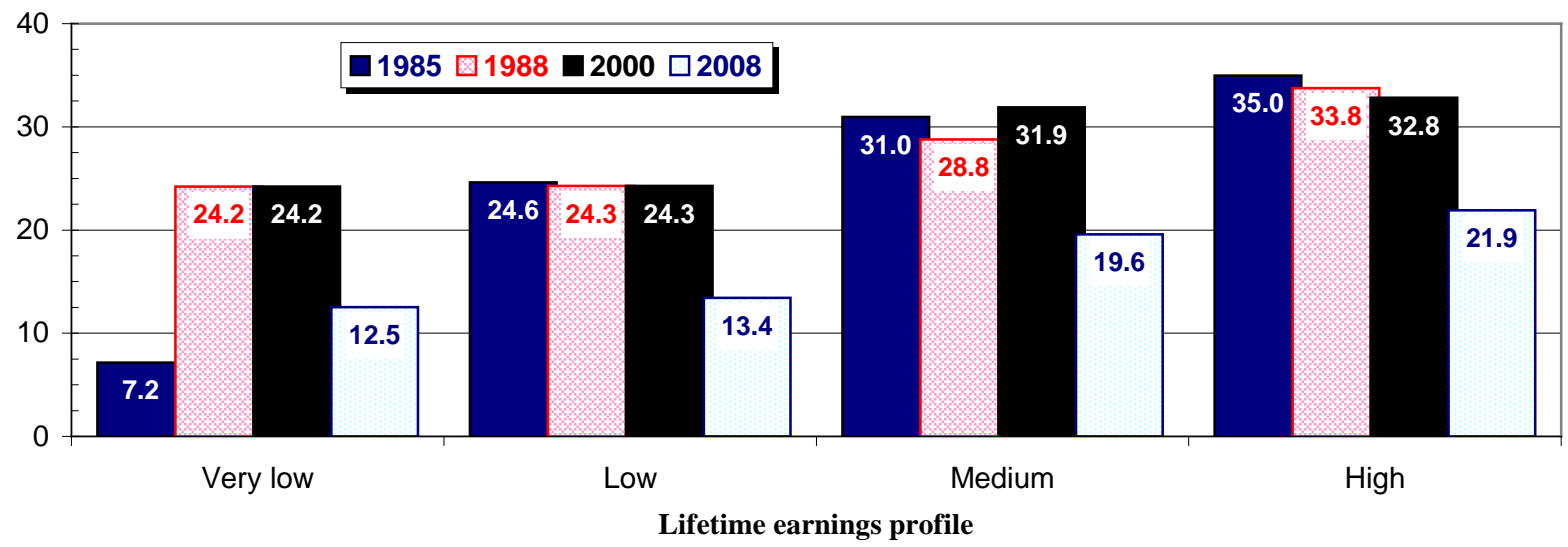

Source: Authors' estimates as explained in text. 


\section{Appendix Table 1. Weighted Reduction in Real Internal Rate of Return If Workers Locate Saving in Ordinary Investment Account or Insurance Plan Rather than a Pension Account: Return Reductions under Alternative Tax Laws $\underline{1}$ /}

Percentage points

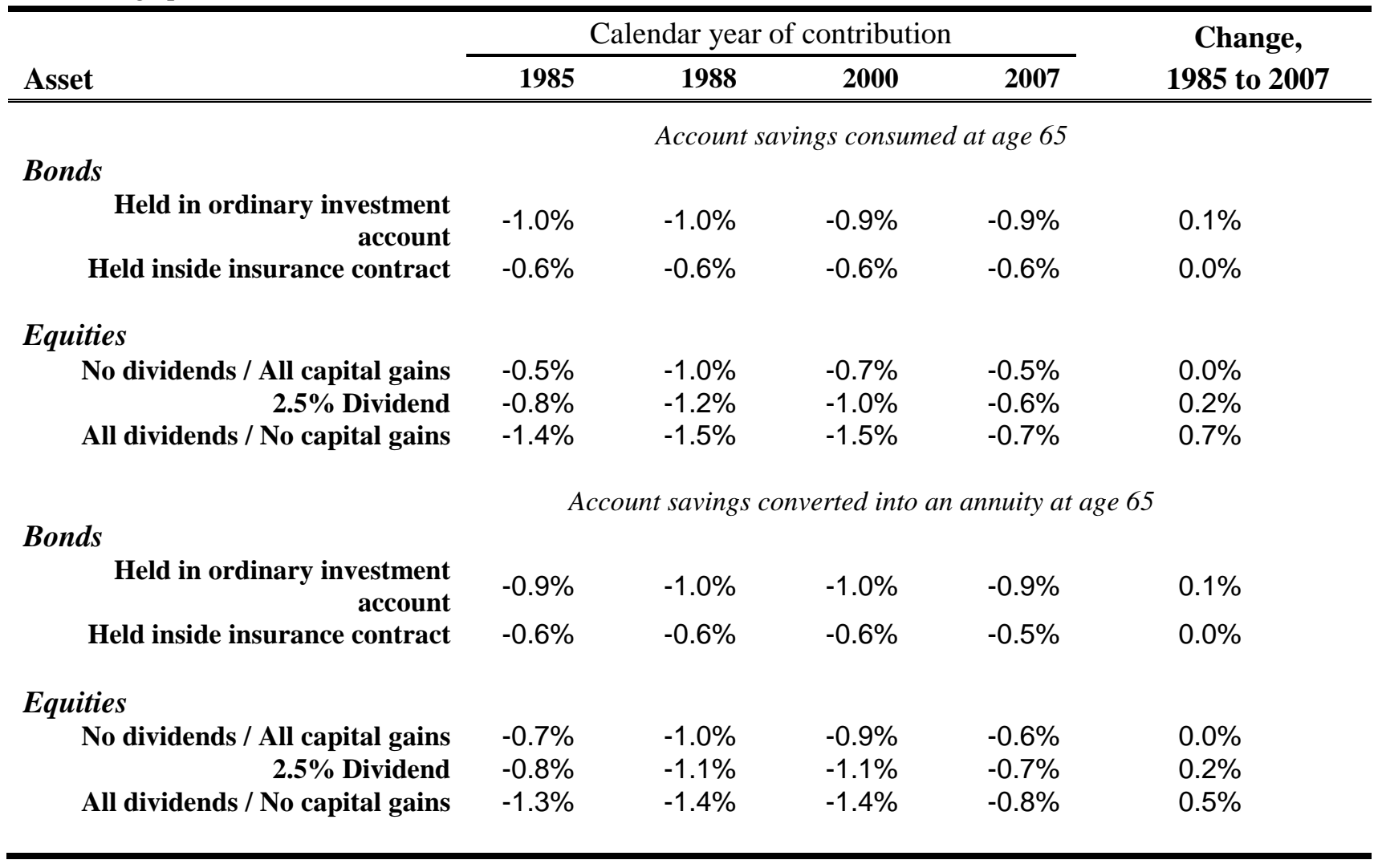

$\underline{1 /}$ Population weights reflect all persons with positive labor earnings in 2007. See text.

Source: Authors' tabulations as described in text. 


\section{Appendix Table 2. Weighted Reduction in Real Internal Rate of Return If Workers Locate Saving in Ordinary Investment Account or Insurance Plan Rather than a Pension Account: Return Reductions under Alternative Tax Laws $\underline{1}$ /}

Percentage points

\begin{tabular}{|c|c|c|c|c|c|}
\hline \multirow[b]{2}{*}{ Asset } & \multicolumn{4}{|c|}{ Calendar year of contribution } & \multirow{2}{*}{$\begin{array}{c}\text { Change, } \\
1985 \text { to } 2007 \\
\end{array}$} \\
\hline & 1985 & 1988 & 2000 & 2007 & \\
\hline & \multicolumn{4}{|c|}{ Account savings consumed at age 65} & \\
\hline \multicolumn{6}{|l|}{ Bonds } \\
\hline $\begin{array}{r}\text { Held in ordinary investment } \\
\text { account }\end{array}$ & $-1.3 \%$ & $-1.2 \%$ & $-1.1 \%$ & $-1.1 \%$ & $0.2 \%$ \\
\hline Held inside insurance contract & $-0.9 \%$ & $-0.8 \%$ & $-0.8 \%$ & $-0.7 \%$ & $0.1 \%$ \\
\hline \multicolumn{6}{|l|}{ Equities } \\
\hline No dividends / All capital gains & $-0.7 \%$ & $-1.3 \%$ & $-0.9 \%$ & $-0.7 \%$ & $0.0 \%$ \\
\hline $2.5 \%$ Dividend & $-1.1 \%$ & $-1.4 \%$ & $-1.2 \%$ & $-0.7 \%$ & $0.3 \%$ \\
\hline All dividends / No capital gains & $-1.8 \%$ & $-1.7 \%$ & $-1.7 \%$ & $-0.9 \%$ & $0.9 \%$ \\
\hline & \multicolumn{5}{|c|}{ Account savings converted into an annuity at age 65} \\
\hline \multicolumn{6}{|l|}{ Bonds } \\
\hline $\begin{array}{r}\text { Held in ordinary investment } \\
\text { account }\end{array}$ & $-1.2 \%$ & $-1.2 \%$ & $-1.2 \%$ & $-1.0 \%$ & $0.2 \%$ \\
\hline Held inside insurance contract & $-0.8 \%$ & $-0.7 \%$ & $-0.8 \%$ & $-0.7 \%$ & $0.1 \%$ \\
\hline \multicolumn{6}{|l|}{ Equities } \\
\hline No dividends / All capital gains & $-0.9 \%$ & $-1.2 \%$ & $-1.1 \%$ & $-0.8 \%$ & $0.1 \%$ \\
\hline $2.5 \%$ Dividend & $-1.1 \%$ & $-1.3 \%$ & $-1.3 \%$ & $-0.8 \%$ & $0.3 \%$ \\
\hline All dividends / No capital gains & $-1.6 \%$ & $-1.6 \%$ & $-1.6 \%$ & $-0.9 \%$ & $0.7 \%$ \\
\hline
\end{tabular}

1/ Population weights reflect all persons who have positive labor earnings and are offered a workplace pension plan in 2007. See text.

Source: Authors' tabulations as described in text. 


\section{RECENT WORKING PAPERS FROM THE}

\section{CENTER FOR RETIREMENT RESEARCH AT BOSTON COLLEGE}

Social Security, Benefit Claiming and Labor Force Participation: A Quantitative General Equilibrium Approach

Selahattin İmrohoroğlu and Sagiri Kitao, March 2010

How Much Is Enough? The Distribution of Lifetime Health Care Costs Anthony Webb and Natalia Zhivan, February 2010

Impact of Immigration on the Distribution of American Well-Being Gary Burtless, December 2009

Actual and Anticipated Inheritance Receipts

Norma B. Coe and Anthony Webb, December 2009

Will Automatic Enrollment Reduce Employer Contributions to 401(k) Plans Mauricio Soto and Barbara A. Butrica, December 2009

How Seniors Change Their Asset Holdings During Retirement

Karen Smith, Mauricio Soto, and Rudolph G. Penner, December 2009

Retirement Security and the Stock Market Crash: What Are the Possible Outcomes?

Barbara A. Butrica, Karen E. Smith, and Eric J. Toder, November 2009

Fees and Trading Costs of Equity Mutual Funds in 401(k) Plans and Potential Savings from ETFs and Commingled Trusts

Richard W. Kopcke, Francis Vitagliano, and Zhenya S. Karamcheva, November 2009

Work Ability and the Social Insurance Safety Net in the Years Prior to Retirement Richard W. Johnson, Melissa M. Favreault, and Corina Mommaerts, November 2009

Dutch Pension Funds in Underfunding: Solving Generational Dilemmas

Niels Kortleve and Eduard Ponds, November 2009

The Wealth of Older Americans and the Sub-Prime Debacle

Barry Bosworth and Rosanna Smart, November 2009

All working papers are available on the Center for Retirement Research website (http://crr.bc.edu) and can be requested by e-mail (crr@bc.edu) or phone (617-5521762). 